\title{
$\beta$-Keto esters from ketones and ethyl chloroformate: a rapid, general, efficient synthesis of pyrazolones and their antimicrobial, in silico and in vitro cytotoxicity studies
}

\author{
Ramasamy Venkat Ragavan', Kalavathi Murugan Kumar², Vijayaparthasarathi Vijayakumar ${ }^{\text {* }}$, \\ Sundaramoorthy Sarveswari ${ }^{1}$, Sudha Ramaiah², Anand Anbarasu' ${ }^{1,2}$, Sivashanmugam Karthikeyan 1,3, \\ Periyasamy Giridharan ${ }^{4}$ and Nalilu Suchetha Kumari ${ }^{5}$
}

\begin{abstract}
Background: Pyrazolones are traditionally synthesized by the reaction of $\beta$-keto esters with hydrazine and its derivatives. There are methods to synthesize $\beta$-keto esters from esters and aldehydes, but these methods have main limitation in varying the substituents. Often, there are a number of methods such as acylation of enolates in which a chelating effect has been employed to lock the enolate anion using lithium and magnesium salts; however, these methods suffer from inconsistent yields in the case of aliphatic acylation. There are methods to synthesize $\beta$-keto esters from ketones like caboxylation of ketone enolates using carbon dioxide and carbon monoxide sources in the presence of palladium or transition metal catalysts. Currently, the most general and simple method to synthesize $\beta$-keto ester is the reaction of dimethyl or ethyl carbonate with ketone in the presence of strong bases which also requires long reaction time, use of excessive amount of reagent and inconsistent yield. These factors lead us to develop a simple method to synthesize $\beta$-keto esters by changing the base and reagent.

Results: A series of $\beta$-keto esters were synthesized from ketones and ethyl chloroformate in the presence of base which in turn are converted to pyrazolones and then subjected to cytotoxicity studies towards various cancer cell lines and antimicrobial activity studies towards various bacterial and fungal strains.

Conclusion: The $\beta$-keto esters from ethyl chloroformate was successfully attempted, and the developed method is simple, fast and applicable to the ketones having the alkyl halogens, protecting groups like Boc and Cbz that were tolerated and proved to be useful in the synthesis of fused bicyclic and tricyclic pyrazolones efficiently using cyclic ketones. Since this method is successful for different ketones, it can be useful for the synthesis of pharmaceutically important pyrazolones also. The synthesized pyrazolones were subjected to antimicrobial, docking and cytotoxicity assay against ACHN (human renal cell carcinoma), Panc-1 (human pancreatic adenocarcinoma) and HCT-116 (human colon cancer) cell line, and lead molecules have been identified. Some of the compounds are found to have promising activity against different bacterial and fungal strains tested.
\end{abstract}

Keywords: $\beta$-keto esters; Ethyl chloroformate; Pyrazolones; Efficient synthesis; Anti-bacterial activity; Fungicidal activity; Cytotoxicity studies

\footnotetext{
* Correspondence: kvpsvijayakumar@gmail.com

${ }^{1}$ Centre for Organic and Medicinal Chemistry, VIT University, Vellore 632014 India

Full list of author information is available at the end of the article
} 


\section{Background}

Pyrazolones are important class of heterocyclic ring systems that have been used extensively in pharmaceutical industry $[1,2]$ due to their numerous applications as analgesic, antipyretic, antiarthritic, uricosuric, anti-inflammatory and antiphlogistic properties. Especially, a pyrazolone derivative (edaravone) [3] acts as a radical scavenger to interrupt the peroxidative chain reactions and membrane disintegrations associated with ischemia [4-6]. Some of the aryloxypyrazolone derivatives are useful in the treatment of a variety of disorders caused by human immunodeficiency virus and other genetic ailments caused by retroviruses such as acquired immune deficiency syndrome [7]. In addition, these compounds are appropriate precursors for industrial preparation of herbicides [8], liquid crystals [9,10], dyes [11], thermally stable polymers [12] and colour photographical compounds [13]. Azadienophiles from the chemical oxidation of pyrazolones are acting as suitable substrates for hetero Diels-Alder reactions [14].

Pyrazolones are traditionally synthesized by the reaction of $\beta$-keto esters with hydrazine and its derivatives [15-21]. There are a number of alternative methods to synthesize pyrazolones which are documented in the literature [22-33] but tend to have serious drawbacks such as step-intensive, carbon monoxide usage and sensitive palladium catalysts. These factors revealed that using $\beta$ keto esters as an intermediate is the broadest and most efficient way to synthesize pyrazolones. There are methods to synthesize $\beta$-keto esters from esters [34-37] (Claisen condensation) and aldehydes [38,39], but these methods have main limitation in varying the substituents. Often, a number of methods such as acylation of enolates of malonates [40,41], acylation of Meldrum's acid [42-45], mixed malonate esters $[46,47]$ and bistrimethylsilylmalonate $[48,49]$ have a chelating effect employed to lock the enolate anion of malonate using lithium and magnesium salts [50,51]; however, these methods suffer from inconsistent yields in the case of aliphatic acylation. There are methods to synthesize $\beta$-keto esters from ketones like caboxylation of ketone enolates [52-54] using carbon dioxide and carbon monoxide sources in the presence of palladium or transition metal catalysts. Currently, the most general and simple method to synthesize $\beta$-keto ester is the reaction of dimethyl or ethyl carbonate with ketone in the presence of strong bases [55,56]. This method requires long reaction time, use of excessive amount of reagent and inconsistent yield. These factors lead us to develop a simple method to synthesize $\beta$-keto esters by changing the base and reagent.

\section{Methods}

\section{Antibacterial study}

The newly synthesized pyrazoles for their antibacterial activity against Escherichia coli (ATTC-25922),
Staphylococcus aureus (ATTC-25923), Pseudomonas aeruginosa (ATTC-27853) and Klebsiella pneumonia (recultured) bacterial strains by the disc diffusion method $[57,58]$. The discs measuring $6.25 \mathrm{~mm}$ in diameter were punched from Whatman No. 1 filter paper (GE Healthcare, Little Chalfont, UK). Batches of 100 discs were dispensed to each screw-capped bottle and sterilized by dry heat at $140^{\circ} \mathrm{C}$ for an hour. The test compounds were prepared with different concentrations using DMF. One milliliter containing 100 times the amount of chemical in each disc was added to each bottle, which contains 100 discs. The discs of each concentration were placed in triplicate in a nutrient agar medium separately seeded with fresh bacteria. The incubation was carried out at $37^{\circ} \mathrm{C}$ for $24 \mathrm{~h}$. Solvent and growth controls were kept, and the zones of inhibition and minimum inhibitory concentrations (MIC) were noted. Results of these studies were given in Table 1 and compared with the standard ciprofloxacin.

\section{Antifungal activity}

Newly synthesized pyrazoles were screened for their antifungal activity against Aspergillus flavus (NCIM no. 524), Aspergillus fumigates (NCIM no. 902), Penicillium marneffei (recultured) and Trichophyton mentagrophytes (recultured) in dimethylsulfoxide (DMSO) by the serial plate dilution method [34-36]. Sabouraud agar media was prepared by dissolving peptone $(1 \mathrm{~g})$, D-glucose $(4 \mathrm{~g})$ and agar $(2 \mathrm{~g})$ in distilled water $(100 \mathrm{~mL})$, and the $\mathrm{pH}$ was adjusted to 5.7. Normal saline was used to make a suspension of spores of fungal strain for lawning. A loopful of particular fungal strain was transferred to $3 \mathrm{~mL}$ of saline to get a suspension of corresponding species. Agar media of $20 \mathrm{~mL}$ was poured into each Petri dish. An excess of suspension was decanted, and the plates were dried by placing them in an incubator at $37^{\circ} \mathrm{C}$ for $1 \mathrm{~h}$. Using an agar, punch wells were made on these seeded agar plates, and 10 to $50 \mu \mathrm{g} / \mathrm{mL}$ of the test compounds in DMSO were added into each labelled well. A control was also prepared for plates in the same way using solvent DMSO. The Petri dishes were prepared in triplicate and maintained at $37^{\circ} \mathrm{C}$ for 3 to 4 days. Antifungal activity was determined by measuring the inhibition zone. The results of these studies were given in Table 2 and compared with the standard ciclopiroxolamine.

\section{Docking studies}

All the synthesized compounds $\mathbf{1}$ to $\mathbf{2 6}$ have been subjected to the docking studies against ACHN (human renal cell carcinoma), Panc-1 (human pancreatic adenocarcinoma) and HCT-116 (human colon cancer) and then subjected to WST-1 cytotoxicity assay. Based on the crystal structures of the target proteins and high- 
Table 1 Antibacterial activity of the newly synthesized compounds

\begin{tabular}{lllll}
\hline $\begin{array}{l}\text { Compound } \\
\text { number }\end{array}$ & S. aureus & E. coli & P. aeruginosa & K. pneumonia \\
\hline $\mathbf{1}$ & $21(6.25)$ & $17(6.25)$ & $18(6.25)$ & $20(6.25)$ \\
\hline $\mathbf{2}$ & $20(6.25)$ & $18(6.25)$ & $19(6.25)$ & $21(6.25)$ \\
\hline $\mathbf{3}$ & $23(6.25)$ & $19(6.25)$ & $20(6.25)$ & $22(6.25)$ \\
\hline $\mathbf{4}$ & $20(6.25)$ & $17(6.25)$ & $18(6.25)$ & $19(6.25)$ \\
\hline $\mathbf{5}$ & $16(100)$ & $17(100)$ & $12(100)$ & $14(100)$ \\
\hline $\mathbf{6}$ & $17(100)$ & $17(100)$ & $11(100)$ & $15(100)$ \\
\hline $\mathbf{7}$ & $26(12.5)$ & $23(12.5)$ & $21(12.5)$ & $20(12.5)$ \\
\hline $\mathbf{8}$ & $19(100)$ & $23(100)$ & $22(100)$ & $16(100)$ \\
\hline $\mathbf{9}$ & $26(6.25)$ & $23(6.25)$ & $21(6.25)$ & $20(6.25)$ \\
\hline $\mathbf{1 0}$ & $22(6.25)$ & $18(6.25)$ & $19(6.25)$ & $21(6.25)$ \\
\hline $\mathbf{1 1}$ & $17(6.25)$ & $21(6.25)$ & $20(6.25)$ & $21(6.25)$ \\
\hline $\mathbf{1 3}$ & $28(12.5)$ & $22(12.5)$ & $25(12.5)$ & $23(12.5)$ \\
\hline $\mathbf{1 4}$ & $29(12.5)$ & $25(12.5)$ & $22(12.5)$ & $21(12.5)$ \\
\hline $\mathbf{1 5}$ & $23(6.25)$ & $20(6.25)$ & $21(6.25)$ & $22(6.25)$ \\
\hline $\mathbf{1 7}$ & $31(12.5)$ & $25(12.5)$ & $27(12.5)$ & $20(12.5)$ \\
\hline $\mathbf{1 9}$ & $18(6.25)$ & $19(6.25)$ & $22(6.25)$ & $20(6.25)$ \\
\hline $\mathbf{2 0}$ & $24(6.25)$ & $25(6.25)$ & $26(6.25)$ & $26(6.25)$ \\
\hline $\mathbf{2 1}$ & $30(12.5)$ & $24(12.5)$ & $25(12.5)$ & $22(12.5)$ \\
\hline $\mathbf{2 3}$ & $24(12.5)$ & $27(12.5)$ & $24(12.5)$ & $23(12.5)$ \\
\hline $\mathbf{2 6}$ & $16(100)$ & $17(100)$ & $12(100)$ & $14(100)$ \\
\hline $\mathbf{2}$ & $21(12.5)$ & $24(12.5)$ & $26(12.5)$ & $22(12.5)$ \\
\hline $21(6.25)$ & $23(6.25)$ & $22(6.25)$ & $20(6.25)$ \\
\hline $23(6.25)$ & $32(6.25)$ & $28(6.25)$ & $24(6.25)$ \\
\hline
\end{tabular}

Zone of inhibition $(\mathrm{mm})$; MIC $(\mu \mathrm{g} / \mathrm{mL})$ given in parenthesis.

throughput molecular docking methods, four phases of Gemdock methods were used. These phases include target protein structure analysis, ligand optimization, molecular docking and post-docking analysis. The macroand small-molecule optimization phase involved in editing the structural coordinates of the target protein and compounds. The third phase was molecular docking method to identify potential leads for the target protein; then, the fourth phase was post-docking analysis to identify best conformation of ligand molecule. In the present study, the coordinates of three cancer target proteins were selected and obtained from the Protein Data Bank (PDB) [59]. The PDB entry 1SVC (pancreatic cancer), 3B8Q (renal cancer) and 4FLH (colon cancer) were selected for structural analysis based on its high-resolution crystallographic structure. For docking studies, the PDB coordinates of obtained target proteins were edited by removing the cocrystallized ligand molecule. The crystallographic water molecules were eliminated from the atomic coordinate file, and the polar hydrogen atoms and Kollman united charges were added to each target protein, followed by structure optimization and refinement using spdbv viewer [60]. The synthesized chemical compound structures were sketched with the help of ChemSketch [61]. A threedimensional (3D) conversion and geometry optimization of all the compounds were performed using chimera [62] for flexible conformations of the compounds during the docking. To study the detailed intermolecular interactions between the target protein and the ligand molecule, automated docking program iGEMDOCK (a generic evolutionary method for molecular DOCKing) software was used [63]. iGEMDOCK integrated the virtual screening, molecular docking, post-screening analysis and visualization steps. We selected nuclear factor kappa $b$ (NF-kb), vascular endothelial growth factor receptor-2 and human phosphoinositide 3-kinase (PI3K-gamma) (PDB ID: 1SVC, 3B8Q and 4FLH, respectively) as target proteins to carry out the docking analysis of our synthesized compounds. The 3D coordinates of each therapeutic target protein were implemented through the GEMDOCK graphical environment interface. Then, the default option

Table 2 Antifungal activities of the newly synthesized compounds

\begin{tabular}{|c|c|c|c|c|}
\hline $\begin{array}{l}\text { Compour } \\
\text { number }\end{array}$ & Trichophyton & Penicillium & A. flavus & A. fumigates \\
\hline 1 & $25(6.25)$ & $23(6.25)$ & $26(6.25)$ & $27(6.25)$ \\
\hline 2 & $24(6.25)$ & $25(6.25)$ & $24(6.25)$ & $26(6.25)$ \\
\hline 3 & $29(6.25)$ & $26(6.25)$ & $27(6.25)$ & $28(6.25)$ \\
\hline 4 & $21(6.25)$ & $22(6.25)$ & $26(6.25)$ & $22(6.25)$ \\
\hline 5 & $16(12.5)$ & $17(12.5)$ & $12(12.5)$ & $14(12.5)$ \\
\hline 6 & $17(12.5)$ & $17(12.5)$ & $11(12.5)$ & $15(12.5)$ \\
\hline 7 & $24(12.5)$ & $21(12.5)$ & $21(12.5)$ & $20(12.5)$ \\
\hline 8 & $26(12.5)$ & $24(12.5)$ & $27(12.5)$ & $23(12.5)$ \\
\hline 9 & $27(12.5)$ & $25(12.5)$ & $28(12.5)$ & $22(12.5)$ \\
\hline 10 & $20(6.25)$ & $22(6.25)$ & $17(6.25)$ & $22(6.25)$ \\
\hline 11 & $21(6.25)$ & $21(6.25)$ & $23(6.25)$ & $21(6.25)$ \\
\hline 13 & $22(12.5)$ & $25(12.5)$ & $27(12.5)$ & $23(12.5)$ \\
\hline 14 & $30(12.5)$ & $22(12.5)$ & $26(12.5)$ & $24(12.5)$ \\
\hline 15 & $26(12.5)$ & $23(12.5)$ & $27(12.5)$ & $23(12.5)$ \\
\hline 17 & $31(12.5)$ & $25(12.5)$ & $28(12.5)$ & $23(12.5)$ \\
\hline 19 & $25(6.25)$ & $24(6.25)$ & $27(6.25)$ & $24(6.25)$ \\
\hline 20 & $28(12.5)$ & $29(12.5)$ & $25(12.5)$ & $25(12.5)$ \\
\hline 21 & $31(12.5)$ & $28(12.5)$ & $27(12.5)$ & $24(12.5)$ \\
\hline 23 & $29(12.5)$ & $27(12.5)$ & $26(12.5)$ & $21(12.5)$ \\
\hline 24 & $23(12.5)$ & $26(12.5)$ & $23(12.5)$ & $25(12.5)$ \\
\hline 25 & $21(6.25)$ & $20(6.25)$ & $21(6.25)$ & $23(6.25)$ \\
\hline 26 & $25(12.5)$ & $22(12.5)$ & $27(12.5)$ & $28(12.5)$ \\
\hline Standard & $27(3.125)$ & $23(6.25)$ & $27(3.125)$ & $26(6.25)$ \\
\hline
\end{tabular}

Zone of inhibition $(\mathrm{mm}), \mathrm{MIC}(\mu \mathrm{g} / \mathrm{mL})$ given in parenthesis and ciclopiroxolamine as standard. 
Table 3 Docking results of synthesized compounds in the binding site of nuclear factor kappa $b$

\begin{tabular}{|c|c|c|c|}
\hline Compound number & Total energy & $Z$ score & VDW \\
\hline 1 & -74.15 & -73.1 & -73.15 \\
\hline 2 & -66.2304 & -70.6 & -56.7448 \\
\hline 3 & -78.2994 & -90.8 & -65.8385 \\
\hline 4 & -42.783 & -45.93 & -68.7026 \\
\hline 5 & -50.5602 & -54.9 & -50.366 \\
\hline 6 & -88.1508 & -110.2 & -70.312 \\
\hline 7 & -32.2859 & -40.6 & -55.3665 \\
\hline 8 & -49.5672 & -50.8 & -56.3479 \\
\hline 9 & -62.3895 & -62.4 & -50.3603 \\
\hline 10 & -74.4438 & -72.3 & -70.4519 \\
\hline 11 & -90.4298 & -117.4 & -80.5608 \\
\hline 12 & -83.3089 & -90.4 & -67.7796 \\
\hline 13 & -42.6816 & -50.3 & -60.7439 \\
\hline 14 & -91.9971 & -119.9 & -74.1695 \\
\hline 15 & -35.7564 & -46.7 & -68.4413 \\
\hline 16 & -72.932 & -69.9 & -60.4764 \\
\hline 17 & -60.4516 & -60.2 & -60.3893 \\
\hline 18 & -34.3128 & -101.7 & -53.5055 \\
\hline 19 & -41.0148 & -50.9 & -63.3827 \\
\hline 20 & -35.2375 & -40.6 & -87.3575 \\
\hline 21 & -79.2554 & -85.2 & -51.5586 \\
\hline 22 & -39.9575 & -42.3 & -67.6976 \\
\hline 23 & -32.1991 & -42.3 & -63.8354 \\
\hline 24 & -58.4277 & -60.9 & -67.0823 \\
\hline 25 & -58.424 & -60.9 & -53.7606 \\
\hline 26 & -30.0129 & -44.6 & -44.8782 \\
\hline
\end{tabular}

was used to import the 3D coordinates of 27 synthesized compounds. Before docking, the output path was set. GEMDOCK default parameters included the population size $(n=200)$, generation $(g=70)$ and number of solutions $(s=10)$ to compute the probable binding conformation of synthesized compounds. Then, the docking run was started using GEMDOCK scoring function. After docking, the individual binding conformation of each ligand was observed, and their binding affinity with the target proteins was analyzed. The best binding pose and binding energy of each ligand was selected. In the postdocking analysis, van der Waals score, $Z$ score and the details of interacted residues were saved in output folder. Protein-ligand binding site was analyzed and visualized using PyMOL [64]. The three-dimensional structures of NF-kb, vascular endothelial growth factor receptor- 2 and human phosphoinositide 3-kinase are analyzed, and synthesized compounds $\mathbf{1}$ to $\mathbf{2 6}$ are optimized to have minimal potential energy using chimera. After minimization, all the ligands are docked into each target protein to study the molecular basis of interaction and binding affinity of all the synthesized compounds. From the docking analysis, we listed best conformers based on total energy, $Z$ score and van der Waals score (VDW) for each ligand molecule (Tables 3,4,5). The best docking poses for each ligand molecule into each target protein are determined, and the one having the lowest binding energy among the 20 different poses generated. The lower energy scores represent better protein-ligand binding affinity compared to higher energy values.

\section{Cytotoxicity studies}

The compounds $\mathbf{1}$ to $\mathbf{2 6}$ have been subjected to cyctotoxicity studies. Towards this, a panel of three cancer cells representing multiple cancers of clinical relevance were obtained from American Type Culture Collection (ATCC), namely ACHN (human renal cell carcinoma), Panc-1 (human pancreatic adenocarcinoma) and HCT116 (human colon cancer). Cells were maintained in Dulbecco's modified Eagle's medium (DMEM) medium containing $10 \%$ heat-inactivated fetal bovine serum and

Table 4 Docking results of synthesized compounds in the binding site of vascular endothelial growth factor receptor-2

\begin{tabular}{|c|c|c|c|}
\hline Compound number & Total energy & $Z$ score & VDW \\
\hline 1 & -75.0934 & -72.2 & -79.4166 \\
\hline 2 & -78.2062 & -75.1 & -69.6532 \\
\hline 3 & -70.5653 & -95.6 & -68.46 \\
\hline 4 & -78.7892 & -72.3 & -63.191 \\
\hline 5 & -65.564 & -78.9 & -59.3404 \\
\hline 6 & -86.6543 & -105.7 & -80.5888 \\
\hline 7 & -71.8927 & -63.17 & -59.0905 \\
\hline 8 & -95.9923 & -120.5 & -94.7849 \\
\hline 9 & -79.948 & -71.9 & -56.0692 \\
\hline 10 & -73.5766 & -80 & -86.6021 \\
\hline 11 & -72.3245 & -73.6 & -73.1902 \\
\hline 12 & -75.4277 & -72.2 & -70.7142 \\
\hline 13 & -85.3265 & -94.6 & -54.4274 \\
\hline 14 & -75.329 & -75.3 & -71.2839 \\
\hline 15 & -80.914 & -75.1 & -73.6739 \\
\hline 16 & -75.3033 & -91.5 & -63.0176 \\
\hline 17 & -68.7853 & -74.3 & -69.6841 \\
\hline 18 & -104.9856 & -125.5 & -105.697 \\
\hline 19 & -92.6464 & -115.2 & -87.8944 \\
\hline 20 & -74.3443 & 76.7 & -70.902 \\
\hline 21 & -62.3597 & -73.3 & -50.6291 \\
\hline 22 & -60.2348 & -78.2 & -65.3015 \\
\hline 23 & -77.191 & -75.6 & -63.8723 \\
\hline 24 & -82.723 & -77.2 & -68.4238 \\
\hline 25 & -80.73 & -75 & -56.4072 \\
\hline 26 & -75.093 & -104.3 & -48.6469 \\
\hline
\end{tabular}


Table 5 Docking results of synthesized compounds in the binding site of phosphoinositide 3-kinase

\begin{tabular}{|c|c|c|c|}
\hline Compound number & Total energy & $Z$ score & VDW \\
\hline 1 & -119.541 & -122.5 & -78.0144 \\
\hline 2 & -67.4663 & 68.3 & -53.8734 \\
\hline 3 & -105.3452 & -90.9 & -68.1224 \\
\hline 4 & -75.0481 & -75 & -70.3258 \\
\hline 5 & -77.1818 & -77.2 & -61.47 \\
\hline 6 & -101.23 & -105.1 & -55.6405 \\
\hline 7 & -96.8291 & -110.9 & -54.3328 \\
\hline 8 & -92.0488 & -92 & -61.893 \\
\hline 9 & -75.3184 & -75.3 & -62.0764 \\
\hline 10 & -119.421 & -120.5 & -76.7195 \\
\hline 11 & 92.8443 & -92.3 & -62.324 \\
\hline 12 & -83.9072 & -83.9 & -85.1019 \\
\hline 13 & -80.5887 & -80.6 & -66.5004 \\
\hline 14 & -107.157 & -102.2 & -62.1177 \\
\hline 15 & -76.9716 & -77 & -70.2072 \\
\hline 16 & -94.8943 & -106.4 & -52.3224 \\
\hline 17 & -90.9786 & -91.4 & -66.5817 \\
\hline 18 & -110.067 & -91 & -80.4918 \\
\hline 19 & -83.2508 & -83.3 & -54.2574 \\
\hline 20 & -76.3532 & -76.3 & -86.3532 \\
\hline 21 & -82.2975 & -82.3 & -54.9572 \\
\hline 22 & -74.2083 & -74.2 & -71.0281 \\
\hline 23 & -81.0895 & -81.1 & -63.5472 \\
\hline 24 & -76.2358 & -76.2 & -58.7925 \\
\hline 25 & -67.4663 & -67.5 & -49.4389 \\
\hline 26 & -80.9917 & -81.1 & -48.6582 \\
\hline
\end{tabular}

kept in humidified $5 \% \mathrm{CO}_{2}$ incubator at $37^{\circ} \mathrm{C}$. Logarithmically, growing cells were plated at a density of $5 \times 10^{3}$ cells/well in a 96-well tissue culture grade micro-plate and allowed to recover overnight. The cells were challenged with varying concentrations of compounds for $48 \mathrm{~h}$. Control cells received standard media containing dimethylsulfoxide vehicle at a concentration of $0.2 \%$. After $48 \mathrm{~h}$ of incubation, cell toxicity was determined by the Cell Counting Kit-8 (CCK-8) reagent (Dojindo Molecular Technologies, Inc., Kumamoto, Japan); (WST-1 [2-(2-methoxy-4-nitrophenyl)-3-(4-nitrophenyl)-5-(2,4disulfophenyl)]-2H-tetrazolium, monosodium salt assay). In accordance with the manufacturer's instructions [36], $5 \mu \mathrm{L} /$ well CCK-8 reagent was added, and plates were incubated for $2 \mathrm{~h}$. Cytotoxicity of all the compounds have been determined by measuring the absorbance on Tecan Sapphire multi-fluorescence micro-plate reader (Tecan $\mathrm{GmbH}$, Crailsheim, Germany) at a wavelength of $450 \mathrm{~nm}$ corrected to $650 \mathrm{~nm}$ and normalized to controls. Each independent experiment was performed thrice and tabulated in Table 6.

\section{Results and discussion}

In continuation of our interest towards the synthesis of $\beta$-keto esters and pyrazolones [65-67], we made an attempt to synthesize $\beta$-keto esters from ethyl chloroformate in the presence of base which in turn are converted into pyrazolones in situ by the addition of either hydrazine or its derivatives, since we hypothesized that an enolate may react cleanly with highly electrophilic ethyl chloroformate to give $\beta$-keto esters. We tested our hypothesis in the synthesis of representative compound 12 by varying the solvents as well as bases (Scheme 1). The effects of base and solvent on the yield of $\mathbf{1 2}$ have been summarized and are given in Table 7.

The formation of $\beta$-keto ester was found to be in better yield when LiHMDS was used as a base. When other bases are used, the formation of $\beta$-keto ester intermediate from ketones was very slow, and the reactions were

Table 6 Cytotoxic activity of the newly synthesized compounds 1 to 26

\begin{tabular}{|c|c|c|c|c|}
\hline \multirow[b]{3}{*}{$\begin{array}{l}\text { Compoun } \\
\text { number }\end{array}$} & \multirow[t]{3}{*}{$\begin{array}{l}\text { Concentration } \\
(\mu \mathrm{g} / \mathrm{mL})\end{array}$} & \multicolumn{3}{|c|}{$\begin{array}{l}\text { Percentage of cytotoxicity/ } \\
\text { anti-proliferation }\end{array}$} \\
\hline & & $\begin{array}{c}\text { Panc1 } \\
\text { (pancreas) }\end{array}$ & $\begin{array}{l}\text { ACHN } \\
\text { (renal) }\end{array}$ & $\begin{array}{r}\text { HCT116 } \\
\text { (colon) }\end{array}$ \\
\hline & & & & \\
\hline 1 & 10 & -75 & -7 & -138 \\
\hline 2 & 10 & -64 & 5 & 1 \\
\hline 3 & 10 & -78 & 0 & -16 \\
\hline 4 & 10 & -10 & 20 & -12 \\
\hline 5 & 10 & -20 & -3 & 6 \\
\hline 6 & 10 & -101 & -25 & -116 \\
\hline 7 & 10 & 14 & -16 & -115 \\
\hline 8 & 10 & -15 & -31 & -107 \\
\hline 9 & 10 & -56 & 19 & 8 \\
\hline 10 & 10 & -75 & -7 & -138 \\
\hline 11 & 10 & -117 & 7 & -107 \\
\hline 12 & 10 & -89 & 13 & -70 \\
\hline 13 & 10 & -14 & 3 & 5 \\
\hline 14 & 10 & -118 & -19 & -123 \\
\hline 15 & 10 & 12 & 5 & 17 \\
\hline 16 & 10 & -71 & -10 & -112 \\
\hline 17 & 10 & -51 & 4 & -102 \\
\hline 18 & 10 & 4 & -41 & -128 \\
\hline 19 & 10 & -10 & -26 & -80 \\
\hline 20 & 10 & 71 & 73 & 79 \\
\hline 21 & 10 & -80 & -5 & -20 \\
\hline 23 & 10 & 12 & -7 & -6 \\
\hline 24 & 10 & 6 & 2 & -103 \\
\hline 25 & 10 & -45 & -18 & -64 \\
\hline 26 & 10 & -7 & -12 & 1 \\
\hline Tannase & 10 & 17.3 & 12.4 & 9.7 \\
\hline
\end{tabular}




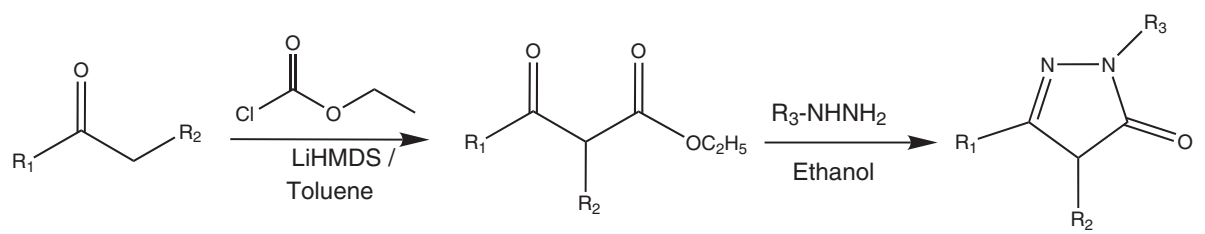

Scheme 1 Synthesis of $\beta$-keto esters from ethyl chloroformate and its conversion into pyrazolones.

also found to be incomplete even after 4 to $5 \mathrm{~h}$ of stirring at r.t. The addition of hydrazine hydrate to the latter reaction mixtures gave the desired product in low yield (Table 8), and the corresponding hydrazone of ketones was isolated as the major product. After finding the suitable base, the reaction conditions were optimized further by varying the solvents to improve the yield. It was found that the hydrocarbon solvent (toluene) produced better yield compared to the cyclic ether solvent (THF). This may be due to the possible destabilization of formed intermediate with charge in the case of hydrocarbon solvent like toluene, and hence, the formed enolate reacts with ethyl chloroformate smoothly.

After optimizing the reaction with the suitable base (LiHMDS) and solvent (toluene), the same conditions were employed for the synthesis of various $\beta$-keto esters which in turn are converted into their corresponding pyrazolones $\mathbf{1}$ to $\mathbf{2 1}$ and $\mathbf{2 3}$ to $\mathbf{2 6}$ in situ by the addition of either hydrazine or its derivatives to prove the generality of the reaction, and the results are tabulated in Table 8 . The reactions have been monitored by thin layer chromatography (TLC), and the obtained crude products were purified by column chromatography. The $\beta$-keto esters were efficiently converted into their corresponding pyrazolones with good to excellent yields. All the synthesized compounds $\mathbf{1}$ to $\mathbf{2 1}$ and $\mathbf{2 3}$ to $\mathbf{2 6}$ have been characterized through IR, ${ }^{1} \mathrm{H}$ NMR, ${ }^{13} \mathrm{C}$ NMR and mass spectral data. The examination of the ${ }^{1} \mathrm{H}$ NMR spectrum of $\mathbf{2 6}$ clearly shows that the formation of doublet at $\delta 1.34 \mathrm{ppm}$ with the coupling constant of $6.92 \mathrm{~Hz}$ integrating for six protons is due to the two methyl groups of isopropyl substituent at C3 of pyrazolone moiety. A multiplet between $\delta 2.79$ and $2.49 \mathrm{ppm}$ integrating for one proton is due to the methine proton of iso-propyl substituent at C3 of pyrazolone moiety. The singlet at $\delta 3.33 \mathrm{ppm}$ integrating for one proton is due to the proton at $\mathrm{C} 4$. Two broad singlets that appeared between $\delta 9.5$ to $9.3 \mathrm{ppm}$ and $\delta 11.2$ to $11.1 \mathrm{ppm}$ integrating for one proton each are due to - $\mathrm{NH}$ and $-\mathrm{OH}$ protons, respectively. This supports the ${ }^{1} \mathrm{H}$ NMR findings that pyrazolone moiety is in its enol rather than the keto form since the spectrum was recorded in deuterated DMSO solvent. Similarly, the examination of the ${ }^{13} \mathrm{C}$ NMR spectrum reveals the following points. The two signals that appeared at aliphatic regions 22.24 and $25.69 \mathrm{ppm}$ are due to methyl and methine carbon, respectively, of the isopropyl substituent at $\mathrm{C} 3$ of the pyrazolone moiety. The signal at $86.22 \mathrm{ppm}$ is due to the C4. The two downfield signals appeared at 160.75 and $150.39 \mathrm{ppm}$. The relatively downfield signal has been assigned as $\mathrm{C} 5$, and the relatively upfield has been assigned as C3. The $m / z$ observed at 126.9 in liquid chromatography-mass spectrometry (LC-MS) spectrum also supports the formation of compound 26. In the similar way, the chemical shifts of all the other compounds have been assigned and are included in the experimental part. Some of the compounds 4, 7, 16, 21, 23 and 24 have been crystallized and subjected to the single crystal X-ray diffraction studies [68-75] and are available in the literature (Ortep plots are included in the Additional file 1); particularly, sample $\mathbf{4}$ has been crystallized as both in keto form and enol form. All the above discussions clearly revealed the formation of the desired products. This method is very simple, fast and applicable to the ketones having the alkyl halogens, protecting groups like Boc and Cbz that were tolerated and proved to be useful in the synthesis of fused bicyclic and tricyclic

Table 7 Effect of solvent and base on the yield of 12

\begin{tabular}{lcccc}
\hline Base & Ketone (eq.) & Solvent & Temperature & Yield (\%) \\
\hline LiHMDS (1.0M THF) (1 eq.) & 3 & THF & $-78^{\circ} \mathrm{C}$ & 68 \\
\hline LiHMDS (1.0M THF) (2 eq.) & 3 & Toluene & $-78^{\circ} \mathrm{C}$ & $-78^{\circ} \mathrm{C}$ \\
\hline KHMDS (3 eq.) & 7 & Toluene & $-78^{\circ} \mathrm{C}$ & 17 \\
\hline $\mathrm{NaH}(2$ eq.) & 50 & THF & Reflux & 0 \\
\hline $\mathrm{NaOMe}(2$ eq.) & 75 & THF & $25^{\circ} \mathrm{C}$ & 19 \\
\hline KOtBu (3 eq.) & 10 & THF & $-50^{\circ} \mathrm{C}$ to-30 \\
\hline LiHMDS (1.0M THF) (3.5 eq.) & 7 & Toluene & 92 \\
\hline
\end{tabular}


Ragavan et al. Organic and Medicinal Chemistry Letters 2013, 3:6
http://www.orgmedchemlett.com/content/3/1/6

Page 7 of 15

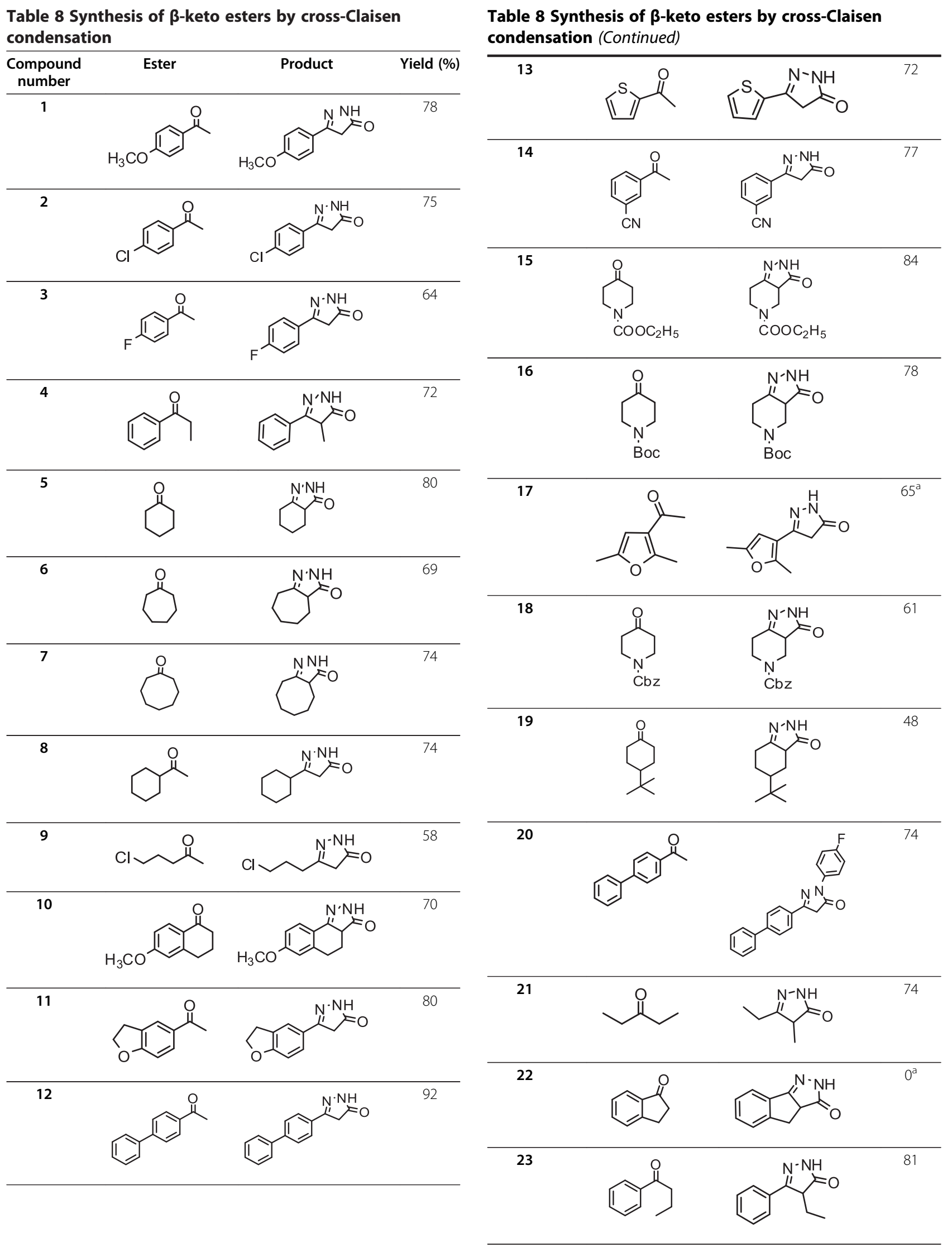


Table 8 Synthesis of $\beta$-keto esters by cross-Claisen condensation (Continued)

24<smiles>CCC(=O)C1CCCCC1</smiles>

25

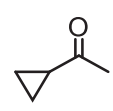

26<smiles>CC(=O)C(C)C</smiles><smiles>CC(C)C1=NNC(=O)C1</smiles>

27<smiles>O=C1CCOc2ccccc21</smiles><smiles>O=C1NN=C2c3ccccc3OCC12</smiles>

apercentage of products in crude LC-MS.

pyrazolones efficiently using cyclic ketones. Since this method is successful for different ketones, it can also be useful for the synthesis of pharmaceutically important pyrazolones.

We have investigated the newly synthesized pyrazoles for their antibacterial activity against E. coli (ATTC25922), S. aureus (ATTC-25923), P. aeruginosa (ATTC27853) and K. pneumonia (recultured) bacterial strains by the disc diffusion method $[57,58]$. Results of these studies were given in Table 1 and compared with the standard ciprofloxacin. Most of the synthesized compounds exhibited very good bacterial activity; particularly, compounds 7, 13, 14, 23, 25 and 26 have shown very good inhibition against all the bacterial strains tested. Compounds 9 to 11, 13, 14, 19, 20 and 26 have shown a moderate to good inhibition against all the bacterial strains. Compounds $\mathbf{8}$ and $\mathbf{2 4}$ have poor bacterial activity. The SAR studies on these compounds revealed that the aliphatic substituents (either cyclic or acyclic) on the main cage increase their biological activities. On the other hand, compounds bearing the aromatic substituents and the fused ring systems decrease their activity. Halogen substitution in alkyl group also reduces their activity. Some of the tested compounds are equipotent or more potent than the standards used.

Newly synthesized pyrazoles were screened for their antifungal activity against $A$. flavus (NCIM no. 524), A. fumigates (NCIM no. 902), P. marneffei (recultured) and T. mentagrophytes (recultured) in DMSO by the serial plate dilution method [34-36]. Most of the tested compounds exhibited good fungicidal activities; particularly, compounds 10, 11, 19 and 25 were found to be highly potent to all the four fungi tested. Compounds $\mathbf{1}$ to $\mathbf{9}$, 13 to $15,17,20,21,23,25$ and 26 were shown to have good to moderate activity to all the fungi tested.

All the synthesized compounds $\mathbf{1}$ to $\mathbf{2 6}$ have been subjected to the docking studies against ACHN (human renal cell carcinoma), Panc-1 (human pancreatic adenocarcinoma) and HCT-116 (human colon cancer) and then subjected to WST-1 cytotoxicity assay. Among the 26 synthesized compounds, compounds 14, 20 and 4 are found to have least binding energy value and $Z$ score value. These compounds are more stable ligand-receptor complex amongst other compounds. Compound 14 shows the best binding conformation with $\mathrm{nf}-\mathrm{kb}$ (total energy $=-91.9971 \mathrm{kcal} / \mathrm{mol}, Z$ score $=-119)$. The best binding mode of compound $\mathbf{1 4}$ at the NF-kb binding site and the residues involved in the interaction, corresponding two-dimensional (2D) interaction models, hydrogen bonds and bond distance are shown in Figure 1. Compound 14 binds to the binding sites and forms three hydrogen bonds with NF-kb involved in pancreatic cancer. It can be seen in Figure 1 that nitrogen atoms of compound 14 formed a hydrogen bond with Pro-65 and
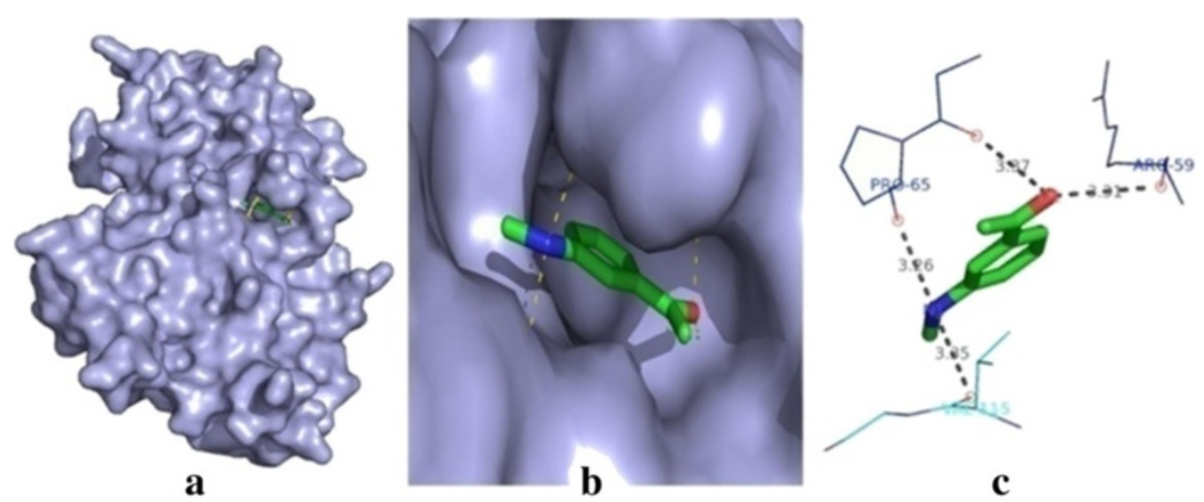

Figure 1 Molecular docking result of compound 14. (a) The docked poses of compound $\mathbf{1 4}$ at the site of nuclear factor kappa b; target protein is shown in the surface model, and the ligand is shown in the stick model. (b) A close-up view of the docked pose of compound $\mathbf{1 4}$. (c) The amino acid residue interaction, hydrogen bond networks in the binding pocket and the distance (in Angstrom units) of bonds are shown. 


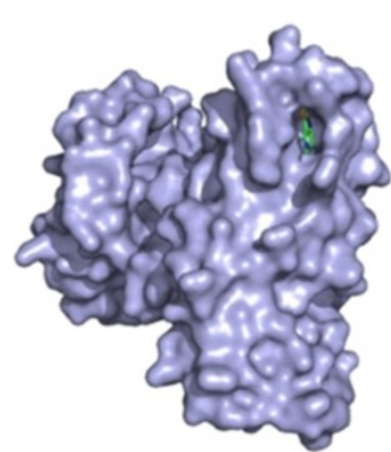

a

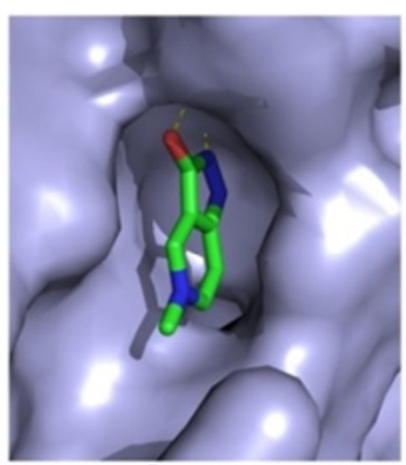

b

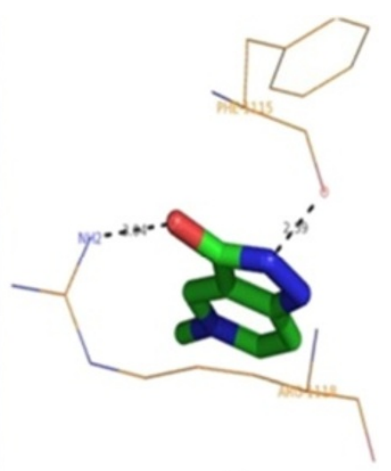

c

Figure 2 Molecular docking result of compound 18. (a) Binding pose of compound $\mathbf{1 8}$ in the vascular endothelial growth factor receptor-2. (b) A close-up view of the binding pose of compound 18; protein structure is shown in the surface model, and the ligand is shown in the stick model. (c) $\mathrm{H}$ bond networks with protein residues are shown.

Val115. In addition, Arg59 has one $\mathrm{H}$ bond with the bond distance of $3.91 \AA$. The binding pose and interaction mode of compound $\mathbf{1 4}$ are shown in Figure 1.

The post-docking analysis of compound $\mathbf{1 8}$ has shown higher affinity with VGFR2 which has key role in renal cancer development (total energy $=-104.9856 \mathrm{kcal} / \mathrm{mol}$, $Z$ score $=-125.5$ ). Compound 18 binds to the VGFR2 and forms one $\mathrm{H}$ bond interaction with Arg118 and Phe115 residues. The best binding pose of compound $\mathbf{1 8}$ in the VGFR2 and corresponding 2D interaction models, hydrogen bonds and bond distance are depicted in Figure 2. Docking analysis of compound $\mathbf{1}$ has shown the best conformation with PI3K (total energy $=-119.541$ $\mathrm{kcal} / \mathrm{mol}, Z$ score $=-125.5)$. The binding affinity of compound $\mathbf{1}$ towards PI3K is investigated in detail. On analysis of the interaction and position of compound $\mathbf{1}$ in the PI3K binding site, it is observed that five $\mathrm{H}$ bonds are found, and the amino acid residues Asp654, Gln846, ARG649 and Trp201 participated in the interaction. The surface of PI3K with compound $\mathbf{1}$ along with the main contact residues of PI3K is labelled, and hydrogen bond distances are shown in Figure 3.

In continuation of the docking analysis, the compounds $\mathbf{1}$ to $\mathbf{2 6}$ have been subjected to the cyctotoxicity studies. Towards this, a panel of three cancer cells representing multiple cancers of clinical relevance were obtained from ATCC, namely ACHN (human renal cell carcinoma), Panc-1 (human pancreatic adenocarcinoma) and HCT-116 (human colon cancer). Cells were maintained in DMEM containing 10\% heat-inactivated fetal bovine serum and kept in humidified $5 \% \mathrm{CO}_{2}$ incubator at $37^{\circ} \mathrm{C}$. Logarithmically growing cells were plated at a density of $5 \times 10^{3}$ cells/well in a 96-well tissue culture grade micro-plate and allowed to recover overnight. The cells were challenged with varying concentration of compounds for $48 \mathrm{~h}$. Control cells received standard media containing dimethylsulfoxide vehicle at a concentration of $0.2 \%$. After $48 \mathrm{~h}$ of incubation, cell toxicity was

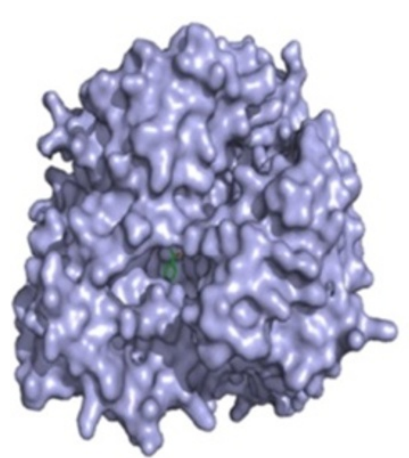

a

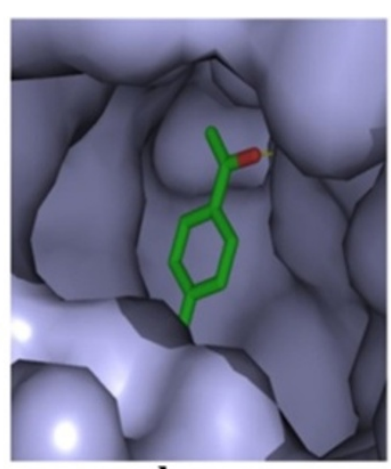

b

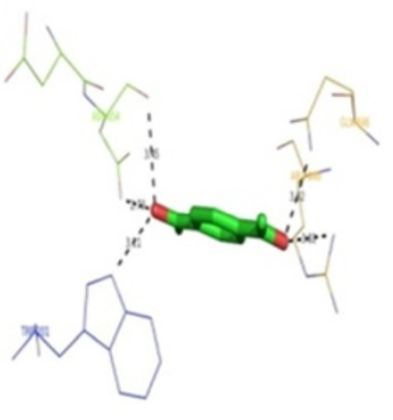

c

Figure 3 Molecular docking result of compound 1. (a) Docked poses of compound $\mathbf{1}$ in human phosphoinositide 3-kinase binding site. (b) A close-up view of the docked pose of compound $\mathbf{1}$; protein structure is shown in the surface model, and the ligand is shown in the stick model (color by atom). (c) $\mathrm{H}$ bond networks and bond distance are shown. 
determined by the CCK- 8 reagent (Dojindo Molecular Technologies, Inc.); (WST-1 [2-(2-methoxy-4-nitrophenyl)-3-(4-nitrophenyl)-5-(2,4-disulfophenyl)]-2H-tetrazolium, monosodium salt assay). In accordance with the manufacturer's instructions [36], $5 \mu \mathrm{L} /$ well CCK-8 reagent was added, and plates were incubated for $2 \mathrm{~h}$. Cytotoxicity of all the compounds have been determined by measuring the absorbance on Tecan Sapphire multifluorescence micro-plate reader (Tecan $\mathrm{GmbH}$, Germany) at a wavelength of $450 \mathrm{~nm}$ corrected to $650 \mathrm{~nm}$ and normalized to controls. Each independent experiment was performed thrice and tabulated in Table 6 . The compound 18 was found to be inhibitive against only ACHN (human renal cell carcinoma) cell lines. The compounds $\mathbf{1}$ and $\mathbf{1 0}$ were found to be inhibitive against HCT-116 (human colon cancer) cell lines. The compound $\mathbf{1 4}$ was found to be inhibitive against Panc-1 (human pancreatic adenocarcinoma) as well as HCT-116 (human colon cancer) cell lines. The docking poses of the compounds $\mathbf{1}, \mathbf{1 0}, \mathbf{1 4}$ and 18 reveals that these molecules are having either more or strong hydrogen bonding interactions with the target molecules which may be due to the presence of either $O$-alkyl or $O$-aryl or cyanide groups in it, and hence, these molecules are found to have better activity.

\section{Experimental \\ General}

All the NMR spectra were recorded using Bruker AMX 400 or Bruker DPX 300 instrument (Billerica, MA, USA) with 5 -mm PABBO BB-1H tubes. ${ }^{1} \mathrm{H}$ NMR spectra were recorded using approximately $0.03 \mathrm{M}$ solutions in $d_{6}$-DMSO at 300 or $400 \mathrm{MHz}$ with tetramethylsilane (TMS) as internal reference. ${ }^{13} \mathrm{C}$ NMR spectra were recorded using approximately $0.05 \mathrm{M}$ solutions in $d_{6}$ DMSO at 75 or $100 \mathrm{MHz}$ with TMS as internal reference. In many cases, pyrazolones were recorded in the enol form, whenever $d_{6}$-DMSO was used as solvent. Melting points were determined by Buchi B-545 apparatus (Golden Valley, MN, USA). LC-MS were obtained using Agilent 1200 series LC (Santa Clara, CA, USA) and MicromasszQ spectrometer (Manchester, UK).

All reagents were purchased from Sigma-Aldrich (St. Louis, MO, USA) and used as received. LiHMDS solutions were kept under nitrogen atmosphere after opening. Dry toluene, $\mathrm{AcOH}$ and $\mathrm{EtOH}$ were supplied by Spectrochem (Mumbai, India). All chemistry was performed under a nitrogen atmosphere using standard techniques. The chromatographic separations were performed over silica gel (230 to 400 mesh) using mixtures of EtOAc and methanol or EtOAc and hexane as eluent. Solvents were removed under reduced pressure on a rotovap. Organic extracts were dried with anhydrous $\mathrm{Na}_{2} \mathrm{SO}_{4}$. Visualization of spots on TLC plates was effected by UV illumination, exposure to iodine vapor and heating the plates dipped in $\mathrm{KMnO}_{4}$ stain.

\section{General procedure to synthesize pyrazolones from ketones}

LiHMDS (1.0 M solution in toluene, $11 \mathrm{mmol}$ ) was added quickly to a solution of ketone $(10 \mathrm{mmol}$ in toluene $(15 \mathrm{~mL})$ using a syringe at $0^{\circ} \mathrm{C}$ under stirring and stirred at this temperature for $10 \mathrm{~min}$; then, ethyl chloroformate $(11 \mathrm{mmol})$ was added quickly. Reaction mixture was slowly $(10 \mathrm{~min})$ brought to room temperature and stirred for $10 \mathrm{~min}$; then, $2 \mathrm{~mL}$ of acetic acid, $15 \mathrm{~mL}$ of ethanol and hydrazine hydrate $(30 \mathrm{mmol})$ were added and refluxed for 15 min. Reaction mixture was concentrated to dryness under reduced pressure and redissolved in ethyl acetate, the organic layer was washed with saturated brine solution, dried over $\mathrm{Na}_{2} \mathrm{SO}_{4}$ and evaporated under reduced pressure. Crude product was purified by recrystallisation using ethanol.

\section{3-(4-Methoxyphenyl)-1H-pyrazol-5(4H)-one (1)}

Purified by recrystallisation using ethanol (white solid), m.p: $221.0^{\circ} \mathrm{C}$ to $222.3^{\circ} \mathrm{C},{ }^{1} \mathrm{H}$ NMR $\left(400 \mathrm{MHz}, d_{6}\right.$-DMSO) $\delta_{\mathrm{H}}: 3.76\left(\mathrm{~s}, 3 \mathrm{H}\right.$, methyl protons of $\left.-\mathrm{OCH}_{3}\right), 5.77(\mathrm{~s}, 1 \mathrm{H}$, proton at C-4), $6.95(\mathrm{~d}, J=8.80 \mathrm{~Hz}, 2 \mathrm{~Hz}, 2 \mathrm{H}$, aryl protons), 7.57 (dd, $J=6.88 \mathrm{~Hz}$ and $1.92 \mathrm{~Hz}, 2 \mathrm{H}$, aryl protons), 9.70 (bs, $1 \mathrm{H},-\mathrm{NH}$ proton), 11.90 (bs, $1 \mathrm{H},-\mathrm{OH}$ proton); ${ }^{13} \mathrm{C}$ NMR (100 MHz, $d_{6}$-DMSO): $\delta 55.19$ (carbon at $\left.-\mathrm{OCH}_{3}\right), 86.26(\mathrm{C}-3), 114.20,123.15,126.17$, 143.09 (aryl carbons), 158.94 (C-4), 161.21 (C-5). MS calculated for $\mathrm{C}_{10} \mathrm{H}_{10} \mathrm{~N}_{2} \mathrm{O}_{2}$ : 190.19. Found: 189.0 (M-1).

\section{3-(4-Chlorophenyl)-1H-pyrazol-5(4H)-one (2)}

Purified by recrystallisation using ethanol (white solid), m.p: $243.5^{\circ} \mathrm{C}$ to $245.0^{\circ} \mathrm{C},{ }^{1} \mathrm{H}$ NMR $\left(400 \mathrm{MHz}, d_{6}\right.$-DMSO) $\delta_{\mathrm{H}}: 5.93(\mathrm{~s}, 1 \mathrm{H}$, proton at C-4), $7.46(\mathrm{~d}, J=6.80 \mathrm{~Hz}, 2 \mathrm{H}$, aryl protons), 7.69 (d, $J=8.40 \mathrm{~Hz}, 2 \mathrm{H}$, aryl protons), 9.70 (bs, $1 \mathrm{H},-\mathrm{NH}$ proton), 12.15 (bs, $1 \mathrm{H},-\mathrm{OH}$ proton); ${ }^{13} \mathrm{C}$ NMR (100 MHz, $d_{6}$-DMSO): $\delta 86.82$ (C-4), 126.44, 128.78, 132.10 (aryl carbons), 142.0 (C-3), 160.70 (C-5). MS calculated for $\mathrm{C}_{9} \mathrm{H}_{7} \mathrm{ClN}_{2} \mathrm{O}$ : 194.61. Found: 195.0 $\left(\mathrm{M}+1\right.$ for $\left.\mathrm{Cl}^{35}\right)$ and $197.0\left(\mathrm{M}+3\right.$ for $\left.\mathrm{Cl}^{37}\right)$.

\section{3-(4-Fluorophenyl)-1H-pyrazol-5-(4H)-one (3)}

Purified by recrystallisation using ethanol (white solid), m.p: $240.0^{\circ} \mathrm{C}$ to $241.5^{\circ} \mathrm{C},{ }^{1} \mathrm{H}$ NMR $\left(400 \mathrm{MHz}, d_{6}\right.$-DMSO) $\delta_{\mathrm{H}}: 5.86(\mathrm{~s}, 1 \mathrm{H}$, proton at C-4), $7.23(\mathrm{t}, J=8.72 \mathrm{~Hz}, 2 \mathrm{H}$, aryl protons), 7.69 (dd, $J=8.30$ and $7.23 \mathrm{~Hz}, 2 \mathrm{H}$, aryl protons), 9.70 (bs, $1 \mathrm{H},-\mathrm{NH}$ proton), 12.00 (bs, $1 \mathrm{H},-\mathrm{OH}$ proton); ${ }^{13} \mathrm{C}$ NMR (100 MHz, $d_{6}$-DMSO): $\delta 86.71$ (C-4), $115.52,115.74,126.82,126.74$ (aryl carbons), 160.41 (C-4), 162.84 (C-5). MS calculated for $\mathrm{C}_{9} \mathrm{H}_{7} \mathrm{FN}_{2} \mathrm{O}$ : 178.10. Found: 177.0 (M-1). 


\section{4-Methyl-3-phenyl-1H-pyrazol-5(4H)-one (4)}

Purified by recrystallisation using ethanol (white solid), m.p: $218.5^{\circ} \mathrm{C}$ to $220.0^{\circ} \mathrm{C},{ }^{1} \mathrm{H}$ NMR (400 MHz, $d_{6}$-DMSO) $\delta_{\mathrm{H}}: 1.99(\mathrm{~s}, 3 \mathrm{H}$, methyl protons at C-4), $7.34(\mathrm{t}, J=7.20$ $\mathrm{Hz}, 1 \mathrm{H}$, para proton of aryl), $7.45(\mathrm{t}, J=8.00 \mathrm{~Hz}, 2 \mathrm{H}$, meta protons of aryl), $7.53(\mathrm{~d}, J=8.00 \mathrm{~Hz}, 2 \mathrm{H}$, ortho protons of aryl), 9.50 (bs, $1 \mathrm{H},-\mathrm{NH}$ proton), 11.70 (bs, $1 \mathrm{H},-\mathrm{OH}$ proton); ${ }^{13} \mathrm{C}$ NMR (100 MHz, $d_{6}$-DMSO): $\delta$ 7.66 (methyl carbon at C-4), 95.98 (C-4), 126.31, 127.49, 128.78, 131.15 (aryl carbons), 139.54 (C-3), 160.28 (C-5). MS calculated for $\mathrm{C}_{10} \mathrm{H}_{10} \mathrm{~N}_{2} \mathrm{O}:$ 174.19. Found: $173.0(\mathrm{M}-1)$.

\section{4,5,6,7-Tetrahydro-2H-indazol-3(3aH)-one (5)}

Purified by recrystallisation using ethanol (white solid), m.p: $286.0^{\circ} \mathrm{C}$ to $288.0^{\circ} \mathrm{C},{ }^{1} \mathrm{H}$ NMR $\left(400 \mathrm{MHz}, d_{6}\right.$-DMSO) $\delta_{\mathrm{H}}: 1.66$ to $1.59(\mathrm{~m}, 4 \mathrm{H}$, four protons of cyclohexane fused ring), $2.21(\mathrm{t}, J=5.20 \mathrm{~Hz}, 2 \mathrm{H}$, two protons of cyclohexane fused ring), $2.42(\mathrm{t}, J=6.0 \mathrm{~Hz}, 2 \mathrm{H}$, two protons of cyclohexane fused ring), 9.95 (bs, $2 \mathrm{H}$ ); ${ }^{13} \mathrm{C} \mathrm{NMR}$ (100 MHz, $d_{6}$-DMSO): $\delta$ 19.35, 21.73, 22.74, 23.32 (carbons of fused cyclohexane part), 98.88 (C-3 of pyrazole ring), 140.19 (C-4 of pyrazole ring), 158.87 (C-5 of pyrazole ring). MS calculated for $\mathrm{C}_{7} \mathrm{H}_{10} \mathrm{~N}_{2} \mathrm{O}$ : 138.08 . Found: $138.16(\mathrm{M}+)$.

\section{3a,4,5,6,7,8-Hexahydrocyclohepta(e)pyrazol-3-(2H)-one (6)}

Purified by recrystallisation using ethanol (white solid), m.p: $220.5^{\circ} \mathrm{C}$ to $221.8^{\circ} \mathrm{C},{ }^{1} \mathrm{H}$ NMR (400 MHz, $d_{6}$-DMSO) $\delta_{\mathrm{H}}: 1.56$ to $1.50(\mathrm{~m}, 4 \mathrm{H}$, four protons of fused cycloheptane), $1.71(\mathrm{~d}, J=5.52 \mathrm{~Hz}, 2 \mathrm{H}$, two protons of fused cycloheptane), $2.29(\mathrm{t}, J=5.60 \mathrm{~Hz}, 2 \mathrm{H}$, two protons of fused cycloheptane), $2.50(\mathrm{t}, J=3.28 \mathrm{~Hz}, 2 \mathrm{H}$, two protons of fused cycloheptane), 9.20 (bs, $1 \mathrm{H},-\mathrm{NH}$ proton), 11.00 (bs, $1 \mathrm{H},-\mathrm{OH}$ proton); ${ }^{13} \mathrm{C} \mathrm{NMR}(100 \mathrm{MHz}$, $d_{6}$-DMSO): $\delta$ 23.04, 27.68, 29.36, 32.01 (carbons of fused cycloheptane ring), 102.81 (C-4) 143.81 (C-3 of pyrazole ring), 159.25 (C-5). MS calculated for $\mathrm{C}_{8} \mathrm{H}_{12} \mathrm{~N}_{2} \mathrm{O}: 152.19$. Found: $153.0(\mathrm{M}+1)$.

\section{4,5,6,7,8,9-Hexahydro-2H-cycloocta(c)pyraol-3(3aH)-one (7)}

Purified by recrystallisation using ethanol (white solid), m.p: $221.6^{\circ} \mathrm{C}$ to $228.8^{\circ} \mathrm{C},{ }^{1} \mathrm{H}$ NMR (400 MHz, $d_{6}$-DMSO) $\delta_{\mathrm{H}}: 1.40(\mathrm{~m}, 4 \mathrm{H}$, protons of fused cyclooctane ring), 1.51 ( $\mathrm{m}, 2 \mathrm{H}$, protons of fused cyclooctane ring), $1.58(\mathrm{~m}, 2 \mathrm{H}$, protons of fused cyclooctane ring), $2.34(\mathrm{t}, J=6.2 \mathrm{~Hz}$, $2 \mathrm{H}$, protons of fused cyclooctane ring), $2.54(\mathrm{t}, J=6.2$ $\mathrm{Hz}, 2 \mathrm{H}$, protons of fused cyclooctane ring), 9.03 (bs, $1 \mathrm{H},-\mathrm{NH}$ proton), 11.00 (bs, $1 \mathrm{H},-\mathrm{OH}$ proton); ${ }^{13} \mathrm{C} \mathrm{NMR}$ (100 MHz, $d_{6}$-DMSO): $\delta$ 20.13, 24.27, 25.50, 25.76, 28.76, 28.94 (carbons of fused cyclooctane ring), 100.42 (C-4), 141.62 (C-3), 159.42 (C-5). MS calculated for $\mathrm{C}_{9} \mathrm{H}_{14} \mathrm{~N}_{2} \mathrm{O}: 166.20$. Found: $167.0(\mathrm{M}+1)$.

\section{3-Cyclohexyl-1H-pyrazol-5(4H)-one (8)}

Purified by recrystallisation using ethanol (white solid), m.p: $241.5^{\circ} \mathrm{C}$ to $243.0^{\circ} \mathrm{C},{ }^{1} \mathrm{H}$ NMR (400 MHz, $d_{6}$-DMSO) $\delta_{\mathrm{H}}: 1.21$ to $1.26(\mathrm{~m}, 1 \mathrm{H}$, proton of cyclohexyl ring), 1.29 to $1.34(\mathrm{~m}, 4 \mathrm{H}$, protons of cyclohexyl ring), 1.63 to 1.71 (m, $3 \mathrm{H}$, protons of cyclohexyl ring), 1.84 to $1.90(\mathrm{~m}, 2 \mathrm{H}$, protons of cyclohexyl ring)), 2.44 to $2.50(\mathrm{~m}, 1 \mathrm{H}$, proton at $\mathrm{C}^{\prime}$ ' of cyclohexyl ring), $5.20(\mathrm{~s}, 1 \mathrm{H}$, proton at $\mathrm{C}-4)$, 9.30 (bs, $1 \mathrm{H},-\mathrm{NH}$ proton), 11.00 (bs, $1 \mathrm{H},-\mathrm{OH}$ proton); ${ }^{13} \mathrm{C}$ NMR (100 MHz, $d_{6}$-DMSO) $\delta: 25.97,26.08,32.66$, 35.60 (carbons of cyclohexyl ring), 86.74 (C-4), 149.83 (C-3), 161.17 (C-5). MS calculated for $\mathrm{C}_{9} \mathrm{H}_{14} \mathrm{~N}_{2} \mathrm{O}: 166.22$. Found: $166.9(\mathrm{M}+)$.

\section{3-(3-Chloropropyl)-1H-pyrazol-5(4H)-one (9)}

Purified by recrystallisation using ethanol (white solid), m.p: $155.8^{\circ} \mathrm{C}$ to $156.5^{\circ} \mathrm{C},{ }^{1} \mathrm{H}$ NMR (400 MHz, $d_{6}$-DMSO) $\delta_{\mathrm{H}}: 2.00$ to $1.93\left(\mathrm{~m}, 2 \mathrm{H}\right.$, methylene protons at $\mathrm{C}^{\prime}$ of propyl), $2.57(\mathrm{t}, J=7.36 \mathrm{~Hz}, 2 \mathrm{H}$, methylene protons at $\mathrm{C}^{\prime}$ ' of propyl), $3.62(\mathrm{t}, 6.40 \mathrm{~Hz}, 2 \mathrm{H}$, methylene protons at C3' of propyl), $5.25(\mathrm{~s}, 1 \mathrm{H}), 9.50$ (bs, $1 \mathrm{H},-\mathrm{NH}$ proton), 11.20 (bs, $1 \mathrm{H},-\mathrm{OH}$ proton); ${ }^{13} \mathrm{C} \mathrm{NMR}(100 \mathrm{MHz}$, $d_{6}$-DMSO): $\delta 23.51$ (C2' of propyl), 37.18 ( $\mathrm{C}^{\prime}{ }^{\prime}$ of propyl), 45.13 (C3' of propyl), 88.56 (C-4), 143.39 (C-3), 161.20 (C-5). MS calculated for $\mathrm{C}_{6} \mathrm{H}_{9} \mathrm{ClN}_{2} \mathrm{O}: 160.60$. Found: 161.0 $\left(\mathrm{M}+1\right.$ for $\left.\mathrm{Cl}^{35}\right)$ and $163.60\left(\mathrm{M}+3\right.$ for $\left.\mathrm{Cl}^{37}\right)$.

7-Methoxy-4,5-dihydro-2H-benzo(g)indazol-23(3aH)-one (10) Purified by recrystallisation using ethanol (white solid), m.p: $116.4^{\circ} \mathrm{C}$ to $118.2^{\circ} \mathrm{C},{ }^{1} \mathrm{H}$ NMR (400 MHz, $d_{6}$-DMSO) $\delta_{\mathrm{H}}: 2.50(\mathrm{t}, J=5.50 \mathrm{~Hz}, 2 \mathrm{H}$, protons of cyclohexyl B ring), $2.82(\mathrm{t}, J=5.6 \mathrm{~Hz}, 2 \mathrm{H}$, protons of cyclohexyl $\mathrm{B}$ ring), $3.75(\mathrm{~s}, 3 \mathrm{H}$, protons of methoxy group), 6.80 (d, $J=7.0 \mathrm{~Hz}, 1 \mathrm{H}$, aryl proton of $\mathrm{C}$ ring), 6.86 (s, $1 \mathrm{H}$, aryl proton of $\mathrm{C}$ ring), 7.43 (d, $J=7.0 \mathrm{~Hz}, 1 \mathrm{H}$, aryl proton of C ring), 9.50 (bs, $1 \mathrm{H},-\mathrm{NH}) ;{ }^{13} \mathrm{C}$ NMR (100 MHz, $d_{6}$ DMSO): $\delta 17.91,30.04,30.52$ (carbons of cyclohexyl B ring), 55.52 (methoxy carbon), 97.83 (C-4), 112.20, 114.59, 114.81, 120.61, 122.61, 138.18, 139.82, 157.82 (C-3), 158.97 (C-5). MS calculated for $\mathrm{C}_{12} \mathrm{H}_{12} \mathrm{~N}_{2} \mathrm{O}_{2}$ : 216.23. Found: 215.0 (M-1).

\section{3-(2,3-Dihydrobenzofuran-5-yl)-1H-pyrazol-5(4H)-one (11)}

Purified by recrystallisation using ethanol (white solid), m.p: $237.5^{\circ} \mathrm{C}$ to $239.0^{\circ} \mathrm{C},{ }^{1} \mathrm{H}$ NMR (400 MHz, $d_{6}$-DMSO) $\delta_{\mathrm{H}}: 3.19(\mathrm{t}, J=8.70 \mathrm{~Hz}, 2 \mathrm{H}$, protons of benzofuran ring), $4.54(\mathrm{t}, J=8.70 \mathrm{~Hz}, 2 \mathrm{H}$, protons of benzofuran ring), $5.74(\mathrm{~s}, 1 \mathrm{H}$, proton at C-4), $6.67(\mathrm{~d}, J=8.28 \mathrm{~Hz}, 1 \mathrm{H}$, aryl proton of benzofuran ring), 7.38 (dd, $J=8.28 \mathrm{~Hz}, 1.82$ $\mathrm{Hz}, 1 \mathrm{H}$, aryl proton of benzofuran ring), 7.51 (s, $1 \mathrm{H}$, aryl proton of benzofuran ring), 9.65 (bs, $1 \mathrm{H},-\mathrm{NH}$ proton), 11.85 (bs, $1 \mathrm{H},-\mathrm{OH}$ proton); ${ }^{13} \mathrm{C} \mathrm{NMR}\left(100 \mathrm{MHz}, d_{6^{-}}\right.$ DMSO): $\delta 28.95$ (C of benzofuran), 71.14 ( $\mathrm{C}$ of benzofuran), 86.16 (C-3), 109.05, 121.84, 123.09, 124.77, 
127.95 (carbons of benzofuran), 143.51 (C-3), 159.50 (carbon of benzofuran), 161.16 (C-5). MS calculated for $\mathrm{C}_{11} \mathrm{H}_{10} \mathrm{~N}_{2} \mathrm{O}_{2}:$ 202.20. Found: $203.0(\mathrm{M}+1)$.

\section{3-(Biphenyl-4-yl)-1H-pyrazol-5(4H)-one (12)}

Purified by recrystallisation using ethanol (white solid), m.p: $236.5^{\circ} \mathrm{C}$ to $265.0^{\circ} \mathrm{C},{ }^{1} \mathrm{H}$ NMR $\left(400 \mathrm{MHz}, d_{6}\right.$-DMSO) $\delta_{\mathrm{H}}: 5.94(\mathrm{~s}, 1 \mathrm{H}$, proton at $\mathrm{C}-4), 7.37(\mathrm{t}, J=7.5 \mathrm{~Hz}, 1 \mathrm{H}$, aryl proton), 7.47 (t, $J=7.5 \mathrm{~Hz}, 2 \mathrm{H}$, aryl protons), 7.76 to $7.69(\mathrm{~m}, 6 \mathrm{H}$, aryl protons), 9.77 (bs, $1 \mathrm{H},-\mathrm{NH}$ proton), 12.13 (bs, $1 \mathrm{H},-\mathrm{OH}$ proton); ${ }^{13} \mathrm{C}$ NMR $\left(100 \mathrm{MHz}, d_{6}-\right.$ DMSO): $\delta 86.88$ (C-4), 125.26, 126.51, 126.97, 127.54, 128.96 (aryl carbons), 139.25 (C-3), 139.50 (C-5). MS calculated for $\mathrm{C}_{15} \mathrm{H}_{10} \mathrm{~N}_{2} \mathrm{O}_{2}$ : 236.26. Found: 235.0 (M-1).

\section{3-(Thiophen-2-yl)-1H-pyrazol-5(4H)-one (13)}

Purified by recrystallisation using ethanol (white solid), m.p: $204.0^{\circ} \mathrm{C}$ to $205.0^{\circ} \mathrm{C},{ }^{1} \mathrm{H}$ NMR $\left(400 \mathrm{MHz}, d_{6}\right.$-DMSO) $\delta_{\mathrm{H}}: 5.67(\mathrm{~s}, 1 \mathrm{H}$, proton at $\mathrm{C}-4), 7.07(\mathrm{bs}, 1 \mathrm{H}$, proton of thiophenyl ring), 7.32 (bs, $1 \mathrm{H}$, proton of thiophenyl ring), 7.42 (bs, $1 \mathrm{H}$, proton of thiophenyl ring), 9.67 (bs, $1 \mathrm{H},-\mathrm{NH}), 12.05$ (bs, $1 \mathrm{H},-\mathrm{OH}$ ). MS calculated for $\mathrm{C}_{7} \mathrm{H}_{6} \mathrm{~N}_{2} \mathrm{OS}: 166.20$. Found: $167.0(\mathrm{M}+1)$.

\section{3-(5-Oxo-4,5-dihydro-1H-pyrazol-3-yl)benzonitrile (14)}

Purified by recrystallisation using ethanol (white solid). ${ }^{1} \mathrm{H}$ NMR $\left(400 \mathrm{MHz}, d_{6}\right.$-DMSO) $\delta_{\mathrm{H}}: 6.02(\mathrm{~s}, 1 \mathrm{H}$, proton at C4), $7.59(\mathrm{t}, J=10.4 \mathrm{~Hz}, 1 \mathrm{H}$, aryl proton), $7.73(\mathrm{~d}, J=10.4$ $\mathrm{Hz}, 1 \mathrm{H}$, aryl proton), 7.99 (d, $J=10.4,1 \mathrm{H}$, aryl proton), $8.12(\mathrm{~s}, 1 \mathrm{H}$, aryl proton), 10.00 (bs, $1 \mathrm{H},-\mathrm{NH}$ proton), 12.02 (bs, $1 \mathrm{H},-\mathrm{OH}$ proton). MS calculated for $\mathrm{C}_{10} \mathrm{H}_{7} \mathrm{~N}_{3} \mathrm{O}$ : 185.18. Found: $184.0(\mathrm{M}-1)$.

Ethyl 3-oxo-2,3,3a,4,6,7-hexahydropyrazolo[4,3-c]pyridine-5caboxylate (15)

Purified by recrystallisation using ethanol (white solid), m.p: $212.5^{\circ} \mathrm{C}$ to $213.8^{\circ} \mathrm{C},{ }^{1} \mathrm{H}$ NMR $\left(400 \mathrm{MHz}, d_{6}\right.$ DMSO) $\delta_{\mathrm{H}}: 1.90(\mathrm{t}, J=7.08 \mathrm{~Hz}, 3 \mathrm{H}$, methyl of ethyl group), $2.50(\mathrm{~m}, 2 \mathrm{H}$, protons of ring $\mathrm{B}), 3.56(\mathrm{t}, J=5.7$ $\mathrm{Hz}, 2 \mathrm{H}$, protons of ring $\mathrm{B}), 4.04(\mathrm{q}, J=7.08 \mathrm{~Hz}, 2 \mathrm{H}$, methylene of ethyl group), 4.18 (s, $2 \mathrm{H}$, protons of ring B), 9.80 (bs, $1 \mathrm{H},-\mathrm{NH}$ proton), 11.30 (bs, $1 \mathrm{H},-\mathrm{OH}$ proton); ${ }^{13} \mathrm{C}$ NMR (100 MHz, $d_{6}$-DMSO): $\delta 14.62$ (methyl carbon of ethyl group), 21.62 (carbon of ring B), 21.92 (methylene carbon of ethyl group), 60.89, 96.06 (C-4 of pyrazole ring), 138.12, 155.08 (C-3 of pyrazole ring), 156.33 ( $\mathrm{C}-5$ of pyrazole ring). MS calculated for $\mathrm{C}_{9} \mathrm{H}_{13} \mathrm{~N}_{3} \mathrm{O}_{3}$ : 211.21. Found: $212.0(\mathrm{M}+1)$.

\section{Tert-butyl 3-oxo-2,3,3a,4,6,7-hexahydropyrazolo[4,3-c] pyridine-5-carboxylate (16)}

Purified by recrystallisation using ethanol (white solid), m.p: $225.5^{\circ} \mathrm{C}$ to $227.5^{\circ} \mathrm{C},{ }^{1} \mathrm{H}$ NMR $\left(400 \mathrm{MHz}, d_{6}\right.$-DMSO) $\delta_{\mathrm{H}}: 1.40(\mathrm{~s}, 9 \mathrm{H}$, methyl protons of Boc), 2.49 (t, $q=1.77$
$\mathrm{Hz}, 2 \mathrm{H}$, protons of ring $\mathrm{B}), 3.51(\mathrm{t}, J=5.72 \mathrm{~Hz}, 2 \mathrm{H}$, protons of ring $\mathrm{B}$ ), 4.13 (s, $2 \mathrm{H}$, protons of ring $\mathrm{B}) ;{ }^{13} \mathrm{C} \mathrm{NMR}$ (100 MHz, $d_{6}$-DMSO): $\delta 21.75$ (carbons of $\mathrm{B}$ ring), (28.08 methyl carbons of Boc group), 59.77 (carbon of B ring), 78.94 (quaternary carbon of Boc), 96.21 (C-4 of pyrazole ring), 138.24 (C-3 carbon of pyrazole ring), 154.19 (C-5 carbon of pyrazole ring), 156.37 (carbonyl carbon of Boc). MS calculated for $\mathrm{C}_{11} \mathrm{H}_{17} \mathrm{~N}_{3} \mathrm{O}_{3}: 239.27$. Found: $239.8(\mathrm{M}+)$.

\section{3-(2,5-Dimethylfuran-3-yl)-1H-pyrazol-5(4H)-one (17)}

Purified by recrystallisation using ethanol (white solid), ${ }^{1} \mathrm{H}$ NMR (400 MHz, $d_{6}$-DMSO) $\delta_{\mathrm{H}}: 2.21$ (s, 3H, methyl proton of furan ring), $2.32(\mathrm{~s}, 3 \mathrm{H}$, methyl proton of furan ring), $5.51(\mathrm{~s}, 1 \mathrm{H}$, proton at $\mathrm{C}-4) 6.27(\mathrm{~s}, 1 \mathrm{H}$, proton of furan ring), 9.60 (bs, $1 \mathrm{H},-\mathrm{NH}$ proton), 11.62 (bs, $1 \mathrm{H},-\mathrm{OH}$ proton). MS calculated for $\mathrm{C}_{9} \mathrm{H}_{10} \mathrm{~N}_{2} \mathrm{O}_{2}:$ 178.18. Found: 179. $0(M+1)$.

\section{Benzyl 3-oxo-2,3,3a,4,6,7-hexahydropyrazolo[4,3-c]pyridine-} 5-carboxylate (18)

Purified by recrystallisation using ethanol (white solid), m.p: $225.4^{\circ} \mathrm{C}$ to $226.1^{\circ} \mathrm{C},{ }^{1} \mathrm{H}$ NMR (400 MHz, $d_{6}$-DMSO) $\delta_{\mathrm{H}}: 2.50$ to $2.56(\mathrm{~m}, 2 \mathrm{H}$, protons of ring $\mathrm{B}), 3.61(\mathrm{~s}, 2 \mathrm{H}$, protons of ring $\mathrm{B}), 4.23(\mathrm{~d}, J=10.80 \mathrm{~Hz}, 2 \mathrm{H}$, protons of ring $\mathrm{B}$ ), 5.10 (s, $2 \mathrm{H}$, protons of methylene of $\mathrm{Cbz}$ group), 7.38 to $7.30(\mathrm{~m}, 5 \mathrm{H}$, aryl protons of $\mathrm{Cbz}), 9.88$ (bs, $1 \mathrm{H},-\mathrm{NH}$ proton), 11.16 (bs, $1 \mathrm{H},-\mathrm{OH}$ proton); ${ }^{13} \mathrm{C}$ NMR (100 MHz, $d_{6}$-DMSO): $\delta 41.27,42.77,66.39$ (carbons of ring B), 86.72 (C-4), 127.69, 127.01, 128.46 (aryl carbons), 136.90 (C-3), 157.72 (C-5). MS calculated for $\mathrm{C}_{14} \mathrm{H}_{15} \mathrm{~N}_{3} \mathrm{O}_{3}$ : 273.28. Found: $273.8(\mathrm{M}+)$.

\section{5-Tert-butyl-4,5,6,7-tetrahydro-2H-indazol-3(3aH)-one (19)} Purified by recrystallisation using ethanol (white solid), m.p: $243.5^{\circ} \mathrm{C}$ to $244.8^{\circ} \mathrm{C},{ }^{1} \mathrm{H}$ NMR (400 MHz, $d_{6}$-DMSO) $\delta_{\mathrm{H}}: 0.89(\mathrm{~s}, 9 \mathrm{H}$, protons of three methyl groups), 1.18 to $1.25(\mathrm{~m}, 2 \mathrm{H}$, protons of ring $\mathrm{B}), 1.85$ to $1.92(\mathrm{~m}, 2 \mathrm{H}$, protons of ring $\mathrm{B}), 2.39$ to $2.29(\mathrm{~m}, 2 \mathrm{H}$, protons of ring $\mathrm{B})$, $2.55(\mathrm{~m}, 1 \mathrm{H}$, proton of ring $\mathrm{B}) ;{ }^{13} \mathrm{C} \mathrm{NMR}\left(100 \mathrm{MHz}, d_{6^{-}}\right.$ DMSO): $\delta 20.73$ (carbons of methyl groups of tertiary group), 22.54, 24.48, 27.81, 27.85, 32.70, 45.50 (quaternary carbon of tertiary group), 99.42 (C-4 of pyrazole ring), 140.46 (C-3 of pyrazole ring), 158.88 (C-5 of pyrazole ring). MS calculated for $\mathrm{C}_{11} \mathrm{H}_{18} \mathrm{~N}_{2} \mathrm{O}: 194.21$. Found: $194.8(\mathrm{M}+)$.

3-(Biphenyl-4-yl)-1-(4-fluorophenyl)-1H-pyrazol-5(4H)-one (20) Purified by recrystallisation using ethanol (white solid), m.p: $156.2^{\circ} \mathrm{C}$ to $157.5^{\circ} \mathrm{C},{ }^{1} \mathrm{H}$ NMR $\left(400 \mathrm{MHz}, d_{6}\right.$-DMSO) $\delta_{\mathrm{H}}: 6.07(\mathrm{~s}, 1 \mathrm{H}$ at $\mathrm{C}-4), 7.31$ to $7.40(\mathrm{~m}, 3 \mathrm{H}$, aryl protons), 7.48 (t, $J=8.0 \mathrm{~Hz}, 2 \mathrm{H}$, aryl protons), 7.07 to 7.33 (m, $4 \mathrm{H}$, aryl protons), 7.83 to 7.93 (m, $4 \mathrm{H}$, aryl protons), 11.94 (bs, $1 \mathrm{H}$, $-\mathrm{OH}$ proton at $\mathrm{C}-5) ;{ }^{13} \mathrm{C}$ NMR $(100 \mathrm{MHz}$, 
$d_{6}$-DMSO): $\delta 85.57$ (C-4), 116.01, 116.24, 123.52, 123.60, $126.10,126.96,127.25,127.94,129.42,132.92,135.74$, 139.91, 140.17 (aryl carbons), 149.69 (C-3), 154.18, 159.05 (aryl carbons), 161.46 (C-5). MS calculated for $\mathrm{C}_{21} \mathrm{H}_{15} \mathrm{FN}_{2} \mathrm{O}$ : 330.55. Found: 329.0 (M-1).

\section{3-Ethyl-4-methyl-1H-pyrazol-5(4H)-one (21)}

Purified by recrystallisation using ethanol (white solid), m.p: $233.4^{\circ} \mathrm{C}$ to $234.1^{\circ} \mathrm{C},{ }^{1} \mathrm{H}$ NMR (400 MHz, $d_{6}$-DMSO) $\delta_{\mathrm{H}}: 1.07(\mathrm{t}, J=7.64 \mathrm{~Hz}, 3 \mathrm{H}$, methyl protons of ethyl group), 1.72 (s, 3H, methyl at C-4), 2.40 (q, $J=7.6 \mathrm{~Hz}$, $2 \mathrm{H}$, methylene protons of ethyl group), 9.50 (bs, $1 \mathrm{H},-\mathrm{OH}$ proton), 10.05 (bs, $1 \mathrm{H},-\mathrm{OH}$ proton); ${ }^{13} \mathrm{C} \mathrm{NMR} \mathrm{(100} \mathrm{MHz,}$ $d_{6}$-DMSO): $\delta$ 11.34 (methyl carbon of ethyl group), 18.35 (methyl group at C-4), 22.99 (methylene carbon of ethyl group), 99.73 (C-4), 147.27 (C-3), 164.86 (C-5). MS calculated for $\mathrm{C}_{6} \mathrm{H}_{10} \mathrm{~N}_{2} \mathrm{O}$ : 126.15 . Found: $128.0(\mathrm{M}+2)$.

\section{4-Ethyl-3-phenyl-1H-pyrazol-5(4H)-one (23)}

Purified by recrystallisation using ethanol (white solid), m.p: $88.3^{\circ} \mathrm{C}$ to $89.1^{\circ} \mathrm{C}$. ${ }^{1} \mathrm{H}$ NMR (400 MHz, $d_{6}$-DMSO) $\delta_{\mathrm{H}}: 1.15(\mathrm{t}, J=7.6 \mathrm{~Hz}, 3 \mathrm{H}$, protons of methyl group), 2.64 (q, $J=7.6 \mathrm{~Hz}, 2 \mathrm{H}$, protons of methylene group), 7.17 to $7.13(\mathrm{~m}, 1 \mathrm{H}), 7.41$ to $7.32(\mathrm{~m}, 3 \mathrm{H}), 10.00$ (bs, $2 \mathrm{H},-\mathrm{OH}$ and $-\mathrm{NH}$ protons); ${ }^{13} \mathrm{C} \mathrm{NMR}\left(100 \mathrm{MHz}, d_{6^{-}}\right.$ DMSO): $\delta 13.57$ (methyl carbon of ethyl group), 19.10 (methylene carbon of ethyl group), 102.27 (C-4), 125.34 (ipso), 128.12 (ortho), 128.60 (meta), 133.88 (para), 142.49 (C-3), 159.20 (C-5). MS calculated for $\mathrm{C}_{11} \mathrm{H}_{12} \mathrm{~N}_{2} \mathrm{O}$ : 188.22. Found: $188.8(\mathrm{M}+)$.

\section{3-Cyclohexyl-4-methyl-1H-pyrazol-5(4H)-one (24)}

Purified by recrystallisation using ethanol (white solid), m.p: $205.4^{\circ} \mathrm{C}$ to $206.2^{\circ} \mathrm{C}$. ${ }^{1} \mathrm{H}$ NMR (400 MHz, $d_{6}$-DMSO) $\delta_{\mathrm{H}}: 1.25$ to $1.28(\mathrm{~m}, 1 \mathrm{H}$, proton of cyclohexyl ring) 1.32 to $1.40(\mathrm{~m}, 4 \mathrm{H}$, protons of cyclohexyl ring), 1.66 to 1.76 $(\mathrm{m}, 8 \mathrm{H}, 5$ protons of cyclohexyl ring and protons of methyl group), 2.40 to $2.50(\mathrm{~m}, 1 \mathrm{H}$, proton of cyclohexyl ring), 9.50 (bs, $1 \mathrm{H},-\mathrm{NH}$ proton) 10.52 (bs, $1 \mathrm{H},-\mathrm{OH}$ proton); ${ }^{13} \mathrm{C}$ NMR (100 MHz, $d_{6}$-DMSO): $\delta 6.91$ (carbon of methyl group), 26.01, 26.53, 31.91, 36.42 (carbons of cyclohexyl ring), 94.38 (C-4), 145.71 (C-3), 160.12 (C-5). MS calculated for $\mathrm{C}_{10} \mathrm{H}_{16} \mathrm{~N}_{2} \mathrm{O}_{2}$ : 180.24. Found: $180.8(\mathrm{M}+)$.

\section{3-Cyclopropyl-1H-pyrazol-5(4H)-one (25)}

Purified by recrystallisation using ethanol, m.p: $215.5^{\circ} \mathrm{C}$ to $216.8^{\circ} \mathrm{C}$ (white solid). ${ }^{1} \mathrm{H}$ NMR $\left(400 \mathrm{MHz}, d_{6}\right.$-DMSO) $\delta_{\mathrm{H}}$ : 0.58 to 0.55 ( $\mathrm{m}, 2 \mathrm{H}$, protons of cyclopropyl), 0.85 to 0.81 (m, $2 \mathrm{H}$, protons of cyclopropyl), 1.75 to 1.68 (m, $1 \mathrm{H}$, proton of cyclopropyl), 9.50 (bs, $1 \mathrm{H},-\mathrm{NH}$ proton), 11.52 (bs, $1 \mathrm{H},-\mathrm{OH}$ proton); ${ }^{13} \mathrm{C} \mathrm{NMR}\left(100 \mathrm{MHz}, d_{6}\right.$-DMSO): $\delta 7.27$ (C-1' of cyclopropyl ring), 7.59 (C-2', 3' of cyclopropyl ring), 85.78 (C-4), 146.75 (C-3), 160.78 (C-5). MS calculated for $\mathrm{C}_{6} \mathrm{H}_{8} \mathrm{~N}_{2} \mathrm{O}: 124.14$. Found: $124.9(\mathrm{M}+)$.

\section{3-Isopropyl-1H-pyrazol-5(4H)-one (26)}

Purified by recrystallisation using ethanol, m.p: $198.2^{\circ} \mathrm{C}$ to $199.4^{\circ} \mathrm{C}$ (white solid). ${ }^{1} \mathrm{H}$ NMR (400 MHz, $d_{6}$-DMSO) $\delta_{\mathrm{H}}: 1.13(\mathrm{~d}, J=6.92 \mathrm{~Hz}, 6 \mathrm{H}), 2.79$ to $2.72(\mathrm{~m}, 1 \mathrm{H}), 5.20$ (s, 1H), 9.32 (bs, 1H, -NH proton), 11.50 (bs, $1 \mathrm{H},-\mathrm{OH}$ proton); ${ }^{13} \mathrm{C}$ NMR (100 MHz, $d_{6}$-DMSO): $\delta 22.24$ (carbon of two $\mathrm{CH}_{3}$ of iso-propyl), 25.69 (methine carbon of iso-propyl), 86.22 (C-4), 150.39 (C-3), 160.75 (C-5). MS calculated for $\mathrm{C}_{6} \mathrm{H}_{10} \mathrm{~N}_{2} \mathrm{O}: 126.15$. Found: $126.9(\mathrm{M}+)$.

\section{Conclusions}

The $\beta$-keto esters from ethyl chloroformate was successfully attempted, and the developed method is simple, fast and applicable to the ketones having the alkyl halogens, protecting groups like Boc and $\mathrm{Cbz}$ that were tolerated and proved to be useful in the synthesis of fused bicyclic and tricyclic pyrazolones efficiently using cyclic ketones. Since this method is successful for different ketones, it can be useful for the synthesis of pharmaceutically important pyrazolones also. All the new pyrazolones were subjected to antimicrobial, docking and cytotoxicity assay against ACHN (human renal cell carcinoma), Panc-1 (human pancreatic adenocarcinoma) and HCT116 (human colon cancer) cell line. Most of them were found to be active against different bacterial and fungal strains tested, and some of them were found to have promising activity. The in silico and cytotoxicity studies reveal that compound $\mathbf{1 8}$ was found to be inhibitive against only ACHN (human renal cell carcinoma) cell lines. The compounds $\mathbf{1}$ and $\mathbf{1 0}$ were found to be inhibitive against HCT-116 (human colon cancer) cell lines. The compound $\mathbf{1 4}$ was found to be inhibitive against Panc-1 (human pancreatic adenocarcinoma) as well as HCT-116 (human colon cancer) cell lines, and hence, further investigations are in need in these promising lead molecules.

\section{Additional file}

Additional file 1: Spectral evidences. A copy of original ${ }^{1} \mathrm{H}$ NMR and ${ }^{13} \mathrm{C}$ NMR spectra of the compounds $\mathbf{1}$ to $\mathbf{2 6}$ has been included.

\section{Competing interests}

The authors declare that they have no competing interests.

\section{Acknowledgements}

The authors are grateful to Syngene International Pvt. Ltd., Bengaluru for providing spectral facilities. They are also thankful to the VIT management for their generous support and facilities.

\section{Author details}

'Centre for Organic and Medicinal Chemistry, VIT University, Vellore 632 014, India. ${ }^{2}$ Medical and Biological Computing Laboratory, School of Biosciences and Technology, VIT University, Vellore 632 014, India. ${ }^{3}$ Industrial 
Biotechnology Division, School of Bio Sciences and Technology, VIT University, Vellore 632 014, India. ${ }^{4}$ Department of Oncology, HCS \& HTS, Piramal Life Sciences Ltd. Guregaon (E), Mumbai 400063, India. ${ }^{5}$ Department of Biochemistry, K.S. Hegde Medical Academy, Deralakatte 574 162, India.

\section{Received: 30 April 2013 Accepted: 19 June 2013} Published: 19 July 2013

\section{References}

1. Ueda TH, Mase N, Oda II (1981) Synthesis of pyrazolone derivatives. XXXIX. Synthesis and analgesic activity of pyrano[2,3,-c]pyrazoles. Chem Pharm Bull 29:3522-3528

2. Hukki J, Laitinen P, Alberty JE (1968) Preparation and pharmacological activity of pyrazole derivatives with potential antihistaminic properties $\|$. An attempted synthesis of 1-phenyl and 1-benzyl-3-methyl-5-pyrazolones aminoalkylated at position 2. Pharm Acta Helv 43:704-712

3. Nakagawa H, Ohyama R, Kimata A, Suzuki T, Miyata N (2006) Hydroxyl radical scavenging by edaravone derivatives: efficient scavenging by 3-methyl-1-(pyridine-2-yl)-5-pyrazolone with an intramolecular base. Bioorg Med Chem Lett 16:5939-5942

4. Kawai H, Nakai H, Suga M, Yuki S, Watanabe T, Saito KI (1997) Effects of a novel free radical scavenger, $\mathrm{MCl}-186$, on ischemic brain damage in the rat distal middle cerebral artery occlusion model. J Pharmacol Exp Ther 281:921-927

5. Watanabe T, Yuki S, Egawa M, Nishi H (1984) Protective effects of MCl-186 on cerebral ischemia: possible involvement of free radical scavenging and antioxidant actions. J Pharmacol Exp Ther 268:1597-1604

6. Wu TW, Zeng LH, Wu J, Fung KP (2002) Myocardial protection of MCl-186 in rabbit ischemia-reperfusion. Life Sci 71:2249-2255

7. Barba O, Jones LH (2004) Pyrazole derivatives as reverse transcriptase inhibitors.. WO Patent 029042 A1, 8 Apr 2004

8. Plath P, Rohr W, Wuerzer B (1980) Herbicides containing 3-aryl-5methylpyrazole-4-carboxylic acid esters. Ger Offen. DE 2920933 A1 1801204 , 4 Dec 1980

9. Cativiela C, Serrano JL, Zurbano MM (1995) Synthesis of 3-substituted pentene-2,4-diones: valuable intermediates for liquid crystals. J Org Chem 60:3074-3083

10. Sugiura S, Ohno S, Ohtani O, Izumi K, Kitamikado T, Asai H, Kato K, Hori M, Fujimura $\mathrm{H}$ (1977) Synthesis and antiinflammatory and hypnotic activity of 5-alkoxy-3-(N-substituted carbomoyl)-1-phenyl pyrazoles. J Med Chem 20:80-85

11. Sabaa MW, Oraby FH, Abdel-Naby AS, Mohamed RR (2006) Organic thermal stabilizers for rigid poly(vinylchloride). Part XII: N-phenyl-3-substituted-5pyrazolone derivatives. Polym Degrad Stab 91:911-923

12. Kendall JD, Duffin GF (1955) Production of 3-pyrazolidones. US Patent: 2,704,762. Chem Abstr 50:2680f

13. Reynolds GA (1955) Photographic developer composition. US Patent: 2,688,548. Chem Abstr 49:596

14. Johnson MP, Moody CJ (1985) Azodienophiles. Diels-Alder reactions of 4-phenyl-1,2,4-triazole-3,5-dione and 5-phenylpyrazole-3-one with functionalised diones. J Chem Soc Perkin Trans 1:71-74

15. Hiremath SP, Saundane AR, Mruthyunjayaswamy BHM (1993) A new method for the synthesis of $6 \mathrm{H}, 11 \mathrm{H}$-indolo[3,2-c]-isoquinolin-5-ones/thiones and their reactions. J Heterocycl Chem 30:603-609

16. Duffy KJ, Darcy MG, Delorme E, Dillon SB, Eppley DF, Miller CE, Giampa L, Hopson CB, Huang Y, Keenan RM, Lamb P, Leong L, Liu N, Miller SG, Price AT, Rosen J, Shaw TN, Smith H, Stark KC, Tain SS, Tyree C, Wiggall KJ, Zhang L, Luengo I (2001) Hydrazinonapthalene and azonapthalene thrombopoietin mimics are nonpeptidyl promoters of megakaryocytopoiesis. J Med Chem 44:3730-3745

17. Jonathan FM, David JB, Kelvin C, John PM, Mark HS (1995) Nove antagonists of platelet-activating factor. 2 . Synthesis and structure-activity relationships of potent and long-acting heterofused[1,5]benzodiazepine and $[1,4]$ diazepine derivatives of 1-phenyl-2-methyl imidazo[4,5-c]pyridine. J Med Chem 38:3524-3535

18. Darin EK, Miller RB, Mark JK (1999) Fused pyrazoloheterocycles: intramolecular $[3+2]$-nitrile oxide cycloadditions applied to syntheses of pyrazolo [3,4-g] [2,1] dihydrobenzoisoxazol(in)es. Tetrahedron Lett 40:3535-3538

19. Janja M, Vinko S (1995) Preparation of homologous pyrazolonedicarboxylates. Heterocycles 41:1207-1218
20. Tietze LF, Steinmetz A (1996) A general and expedient method for the solid-phase synthesis of structurally diverse 1-phenylpyrazolone derivatives. Synlett:667-668

21. Kuo S, Huang L, Nakamura K (1984) Studies on heterocyclic compounds. 6. Synthesis and analgesic and anti-inflammatory activities of 3,4-dimethylpyrano[2,3-c] pyrazol-6-one. J Med Chem 27:539-544

22. Boeckman RK, Jr, Reed JE, Ge P (2001) A novel route to 2,3-pyrazol-1 $(5 H)$-ones via palladium-catalyzed carbonylation of 1,2-diaza-1,3-butadienes. Org Lett 3:3651-3653

23. Hans N, Gernot K, Juergen DH (1985) Hydrazidine, IV. Reaktion von Hydrazidinenmit 1,2-bifunktionellen Verbindungen. Liebigs Ann Chem GE 1:78-89

24. Habi A, Gravel D (1994) Efficient 1,3 ester shift in a-disubstituted $\beta$-keto ester enolates. Remarkable influence of the metal counterion on the rate of reaction. Tetrahedron Lett 35:4315-4318

25. Gavrilenko BB, Miller SI (1975) Synthesis and properties of 3-amino-3-pyrazolin-5-ones. J Org Chem 40:2720-2724

26. Hu Q, Guan H, Hu C (1995) Synthesis of 3-hydrox-5-per(poly) fluoroalkylpyrazoles. J Fluorine Chem 75:51-54

27. Al-Jallo HN, Al-Khashab A, Sallomi IG (1972) Reactions of unsaturated tetra and tri-esters with hydrazine hydrate and semicarbazide hydrochloride. J Chem Soc Perkin Trans 1:1022-1023

28. Zhang Q, Lu L (2000) A novel synthetic route to ethyl 3-substituted-trans2,3-difluoro-2-acrylates and their reactions with nucleophiles. Tetrahedron Lett 41:8545-8548

29. Omar MT, Sherif FA (1981) New synthetic route to 3-oxo-5-phenyl-2, 3-dihydro-pyrazoles. Synthesis:742-743

30. Tietze LT, Evers H, Hippe T, Steinmetz A, Topkin E (2001) Solid-phase synthesis of substituted pyrazolones from polymer-bound beta-ketoesters. Eur J Org Chem 2001(9):1631-1634

31. Kobayashi S, Furuta T, Sugaita K, Oyamada H (1998) Use of acyl hydrazones as electrophiles in Mannich-type reactions, $\beta$-lactam, pyrazolidinone, and pyrazolone synthesis. Synlett:1019-1021

32. Oyamada H, Kobayashi S (1998) Rare earth triflate-catalyzed addition reactions of acylhydrazones with silyl enolates. A facile synthesis of pyrazole derivatives. Synlett:249-250

33. Kobayashi S, Furuta T, Sugita D, Okitsu O, Oyamada H (1999) Polymer-supported acylhydrazones. Use of $\mathrm{Sc}(\mathrm{OTf})_{3}$-catalyzed Mannich-type reactions providing an efficient method for the preparation of diverse pyrazolone derivatives. Tetrahedron Lett 40:1341-1344

34. Adkins H, Elofson RM, Rossow AG, Robinson CC (1949) The oxidation potentials of aldehydes and ketones. J Am Chem Soc 71:3622-3629

35. Pratt DD, Robinson R (1925) A synthesis of pyrylium salts of anthocyanidin type. Part V. The synthesis of cyanidin chloride and of delphinidin chloride. J Chem Soc Trans 127:166-175

36. Stahler G, Waltersdorfer A (1984) 1-Alkyl-3-alkoxymethyl-4-alkoxy-5-dialkyl carbamethoxypyrazoles and use as aphicides. US Patent: 4447444 A. Chem Abstr 101:151840

37. Petersen JM, Hauser CR (1949) Acylation of certain a-alkoxy and a-aryloxy ketones and esters. J Am Chem Soc 71:770-773

38. Hiroaki M, Haruro I, Masakazu I (2008) Selective synthesis of a-substituted $\beta$-ketoesters from aldehydes and diazoesters on memoporous silica catalysts. Tetrahedron Lett 49:4788-4791

39. Yadav JS, Subba Reddy BV, Eeshwaraiah B, Reddy PN (2005) Niobium (V) chloride-catalyzed $\mathrm{C}-\mathrm{H}$ insertion reactions of a-diazoesters: synthesis of a-ketoesters. Tetrahedron 61:875-878

40. Barbieri G, Seonane G, Trabazo JL, Riva A, Umpierrez F, Radesca L, Tubio R, Kart LD, Hudicky T (1987) General method of synthesis for natural long-chain B-diketones. J Nat Products 50:646-649

41. Maibaum J, Rich DH (1988) A facile synthesis of statine and analogs by reduction of $\beta$-keto esters from Boc-protected amino acids. HPLC analyses of their enantiomeric purity. J Org Chem 53:869-873

42. Schmidt HW, Kalde M (1988) A convenient synthesis of $\beta$-ketodiesters. Org Prep Proced Int 20:184-187

43. Mills FD, Mills GD, Brown RT (1989) Synthesis of methylene-linked pyrethroids. J Agr Food Chem 37:501-507

44. Oikawa Y, Sugano K, Yonemitsu O (1978) Meldrum's acid in organic synthesis. 2. A general and versatile synthesis of beta keto esters. J Org Chem 43:2087-2088

45. Khoukhi N, Vaultier M, Carrie R (1987) Synthesis and reactivity of methyl $\gamma$-azido and ethyl $\sigma$-azidovalarates and of the corresponding acid chlorides as useful reagents for the aminoalkylation. Tetrahedron 43:1811-1822 
46. Chu DTW, Maleczka RE (1987) Synthesis of 4-oxo-4H-quino[2,3,4-i, j] [1,4] benoxazine-5-carboxylic acid derivatives. J Heterocycl Chem 24:453-456

47. Mansour TS, Evans CA (1990) Decarboxylative carbon acylation of malonates with aminoacylimidazoles mediated by lewis acids. Synthetic Commun 20:773-781

48. Rathke M, Nowak MA (1985) Synthesis of beta-keto acids and methyl ketones using bis(trimethylsilyl) malonate and triethylamine in the presence of lithium or magnesium halides. Synthetic Commun 15:1039-1049

49. Taylor EC, Turchi I (1978) A convenient synthesis of $\beta$-ketoesters. Org Prep Proced Int 10:221-224

50. Mellow DS, Baumgarten E, Hauser CR (1994) A new synthesis of betaketoesters of the type $\mathrm{RCOCH}_{2} \mathrm{COOC}_{2} \mathrm{H}_{5}$. J Am Chem Soc 66:1286

51. Banerji A, Jones RB, Mellows G, Phillips L, Sim KY (1976) Fusicoccin. Part 6. Biosynthesis of fusicoccin from $\left[3-{ }^{13} \mathrm{C}\right]$ and $(4 \mathrm{R})-\left[4-{ }^{3} \mathrm{H}\right]-$ mevalonic acid. J Chem Soc Perkin Trans 1:2221-2228

52. Tetsuo T, Yoshiki C, Takeo S (1980) A copper(I)-bicarbonato complex. A water-stable reversible carbon dioxide carrier. J Am Chem Soc 102:431-433

53. Hamed O, El-Qisairi A, Patrick MH (2000) Palladium(II) catalyzed carbonylation of ketones. Tetrahedron Lett 41:3021-3024

54. Mori H, Satake Y (1985) Carboxylation of cyclohexanone with carbon dioxide and potassium phenoxide. Dependence of the reaction upon the amount of carbon dioxide complexed with potassium phenoxide. Chem Pharm Bull 33:3469-3472

55. Robert L, Charles RH (1944) The carbethoxylation and carbonylation of ketones using sodium amide. Synthesis of $\beta$-ketoester. J Am Chem Soc $66: 1768-1770$

56. Wallingford Jones $H$ (1941) Alkyl carbonatres in synthetic chemistry. Condensation with ketones. Synthesis of $\beta$-ketoesters. J Am Chem Soc 63:2252-2254

57. Cruickshank R, Duguid JP, Marmion BP, Swain RHA (1975) Medicinal microbiology, 12th edn, vol 2. Churchill Livingstone, London, p 196

58. Collins AH (1976) Ed., Microbiological Methods, 2nd edition. Butterworth, London

59. Berman HM, Westbrook J, Feng Z, Gilliland G, Bhat TN, Weissig H, Shindyalov IN, Bourne PE (2000) The Protein Data Bank. Nucleic Acids Res 28:235-242

60. Guex N, Peitsch MC (1997) SWISS-MODEL and the Swiss-Pdb Viewer: an environment for comparative protein modeling. Electrophoresis 18:2714-2723

61. Li Z, Wan H, Shi Y, Ouyang P (2004) Personal experience with four kinds of chemical structure drawing software: review on ChemDraw, ChemWindow ISIS/Draw, and ChemSketch. J Chem Inf Comput Sci 44(5):1886-1890

62. Pettersen EF, Goddard TD, Huang CC, Couch GS, Greenblatt DM (2004) UCSF Chimera-a visualization system for exploratory research and analysis. J Comput Chem 5:1605-1612

63. Yang J-M, Chen C-C (2004) GEMDOCK: a generic evolutionary method for molecular docking. Proteins: Structure, Function and Bioinformatics 55:288-304

64. Seeliger D, de Groot BL (2010) Ligand docking and binding site analysis with PyMOL and AutodockNina. J Comput Aided Mol Des 24(5):417-422

65. Venkat Ragavan R, Vijayakumar V, Sucheta Kumari N (2009) Synthesis of some novel bioactive 4-oxy/thio substituted-1H-pyrazol-5(4H)-ones via efficient cross-Claisen condensation. Eur J Med Chem 44:3852-3857

66. Venkat Ragavan R, Vijayakumar V, Sucheta Kumari N (2010) Synthesis and antimicrobial activities of novel 1,5-diaryl pyrazoles. Eur J Med Chem 45:1173-1180

67. Venkat Ragavan R, Vijayakumar V (2010) A novel route to 4-oxy/thio substituted-1H-pyrazol-5(4H)-ones via efficient cross-Claisen condensation. J Heterocyclic Chem 48:323-330

68. Loh WS, Fun HK, Venkat Ragavan R, Vijayakumar V, Sarveswari S (2011) 4-Methyl-5-phenyl-1H-pyrazol-3(2H)-one. Acta Cryst E67:0151-0152

69. Shahani T, Fun HK, Venkat Ragavan R, Vijayakumar V, Sarveswari S (2010) 4-Methyl-5-phenyl-1H-pyrazol-3-ol. Acta Cryst E66:01697-01698

70. Fun HK, Yeap CS, Venkat Ragavan R, Vijayakumar V, Sarveswari S (2010) 4,5,6,7,8,9-Hexahydro-2H-cycloocta-[c]pyrazol-1-ium-3-olate. Acta Cryst E66:03019

71. Shahani T, Fun HK, Venkat Ragavan R, Vijayakumar V, Sarveswari S (2010) Tert-butyl 3-oxo-2,3,4,5,6,7-hexahydro-1H-pyrazolo[4,3-c]pyridine-5carboxylate. Acta Cryst E66:0142-0143

72. Shahani T, Fun HK, Venkat Ragavan R, Vijayakumar V, Sarveswari S (2010) 5-Ethyl-4-methyl-1H-pyrazol-3(2H)-one. Acta Cryst E66:01357-01358
73. Rathore RS, Narasimhamurthy $T$, Venkat Ragavan R, Vijayakumar V, Sarveswari S (2011) 3-Ethyl-4-methyl-1H-pyrazol-2-ium-5-olate. Acta Cryst E67:02129

74. Loh WS, Fun HK, Venkat Ragavan R, Vijayakumar V, Venkatesh M (2011) 5-Ethyl-4-phenyl-1H-pyrazol-3(2H)-one. Acta Cryst E67:0403-0404

75. Shahani T, Fun HK, Venkat Ragavan R, Vijayakumar V, Sarveswari S (2010) 5-Cyclohexyl-4-methyl-1H-pyrazol-3(2H)-one monohydrate. Acta Cryst E66:02760-02761

doi:10.1186/2191-2858-3-6

Cite this article as: Ragavan et al.: $\beta$-Keto esters from ketones and ethyl chloroformate: a rapid, general, efficient synthesis of pyrazolones and their antimicrobial, in silico and in vitro cytotoxicity studies. Organic and Medicinal Chemistry Letters 2013 3:6

\section{Submit your manuscript to a SpringerOpen ${ }^{\circ}$ journal and benefit from:}

- Convenient online submission

- Rigorous peer review

- Immediate publication on acceptance

- Open access: articles freely available online

- High visibility within the field

- Retaining the copyright to your article

Submit your next manuscript at $>$ springeropen.com 